\title{
Spatial, temporal and vertical distribution of ammonia concentrations over Europe - comparing a static and dynamic approach with WRF-Chem
}

M. Werner ${ }^{1}$, M. Kryza ${ }^{2}$, C. Geels ${ }^{3}$, T. Ellermann ${ }^{3}$, and C. Ambelas Skjøth ${ }^{1}$

${ }^{1}$ National Pollen and Aerobiology Research Unit, University of Worcester, Worcester, UK

${ }^{2}$ Department of Climatology and Atmosphere Protection, University of Wrocław, Wrocław, Poland

${ }^{3}$ Department of Environmental Science, Aarhus University, Aarhus, Denmark

Received: 16 June 2015 - Accepted: 5 August 2015 - Published: 26 August 2015

Correspondence to: M. Werner (m.werner@worc.ac.uk)

Published by Copernicus Publications on behalf of the European Geosciences Union.
$\mathrm{NH}_{3}$ concentrations

over Europe - a static and dynamic approach with WRF-Chem

M. Werner et al.

\section{Title Page}

14 


\section{Abstract}

The study focuses on the application of a dynamic ammonia emission into the Weather Research and Forecasting Chemistry model (WRF-Chem) and the influence on the simulated ammonia concentrations and the overall model performance. We have focused on agricultural ammonia sources and have analysed both hourly and daily patterns of ammonia emissions and concentrations at measurement sites located in agricultural areas or influenced by this activity. For selected episodes, we have also investigated the 3-D patterns of the ammonia concentrations in the atmosphere. The application of the dynamic ammonia emission into the WRF-Chem model (the "DYNAMIC" simulation) results in an improvement of the modelled daily ammonia concentrations in comparison to a static approach (the "BASE" simulation), which is currently widely used in chemical transport models. In the case of hourly resolution, we have observed an improvement for the DYNAMIC approach for the winter and autumn seasons, but for the entire year the modelled hourly ammonia peaks are shifted toward the afternoon hours if compared with measurements. This study indicates that the current description of the diurnal cycle of the ammonia concentration from fields is not accurate and more research is needed in order to improve the processes that describe the emission from fertilised fields. The results suggest that the governing processes in relation to the diurnal cycle are the atmospheric mixing and the emission strength. Therefore, an improved description of the diurnal profile of ammonia concentrations within atmospheric models requires a better description of the planetary boundary layer height and a stronger daily pattern of ammonia emission, e.g. through increased evaporation or increased fluxes from the surface.

\section{Introduction}

25 Ammonia $\left(\mathrm{NH}_{3}\right)$ is the most abundant form of reduced nitrogen in the gas-phase within the atmosphere (Behera et al., 2013). Ammonia contributes to both formation of partic-
ACPD

15, 22935-22973, 2015

$\mathrm{NH}_{3}$ concentrations

over Europe - a static and dynamic approach with WRF-Chem

M. Werner et al.

\section{Title Page}

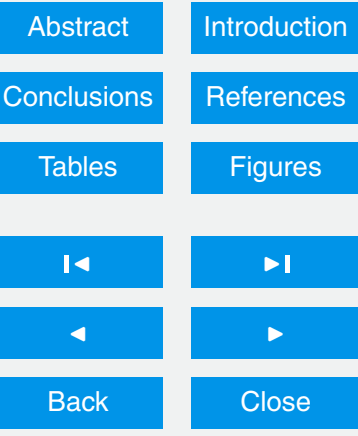

Full Screen / Esc

Printer-friendly Version

Interactive Discussion 
ulate matter (PM) and deposition of reactive nitrogen to the environment (Banzhaf et al., 2013; Hertel et al., 2012; Reis et al., 2009). Ammonia plays a decisive role in particulate matter formation chemistry by determining the amount of ammonium sulphate and ammonium nitrate as PM constituents (Bessagnet et al., 2014). Erisman et al. (2008) 5 estimate that $\mathrm{NH}_{3}$ emissions from agriculture give a substantial contribution (13\%) to the PM concentration in Europe and thereby adds significantly to the external costs related to air pollution in Europe (Brandt et al., 2013). The deposition of nitrogen in the form of ammonia can result in eutrophication of sensitive ecosystems and to acidification of the soil (Bouwman et al., 1997). An enhanced load of nitrogen in terrestrial 10 ecosystems has been found to correlate with loss of biodiversity (Stevens et al., 2004) and can increase ecosystem vulnerability to extreme weather and insect attacks (Bobbink et al., 2010). Despite the importance, there are still many knowledge gaps on ammonia. Long term observational data series are in general scarce compared to e.g. ozone (Tørseth et al., 2012), and hourly observations of ammonia are even more rare due to limitations in existing monitoring networks such as EMEP (Tørseth et al., 2012). Agriculture was responsible for $94 \%$ of the total $\mathrm{NH}_{3}$ emissions in the EU in 2010 (European Environment Agency, http://www.eea.europa.eu/). Agricultural emissions are related to farm buildings, manure, fertilisers and grazing animals, and are strongly influenced by climate and weather (Skjøth and Geels, 2013). $\mathrm{NH}_{3}$ emission varies primarily with temperature and air velocity (Monteny and Erisman, 1998). The volatilization potential nearly doubles for every $5^{\circ} \mathrm{C}$ and varies significantly through the day and season (Gyldenkærne et al., 2005; Sutton et al., 2013). $\mathrm{NH}_{3}$ emission is also controlled by water availability, which allows nitrogen compounds to dissolve, be taken up by organisms and be released through decomposition (Sutton et al., 2013). The regional variation reflects local production methods and agricultural practice, which to a large extend is governed by regional scale climate conditions (Skjøth et al., 2011). Despite these well-known dependencies of climate and meteorology on ammonia emissions, the emissions are handled in a very simplified manner in most atmospheric models (Skjøth et al., 2011). Many integrated effects of meteorology and climate on ammonia

\section{ACPD}

15, 22935-22973, 2015

$\mathrm{NH}_{3}$ concentrations

over Europe - a static and dynamic approach with WRF-Chem

M. Werner et al.

\section{Title Page}

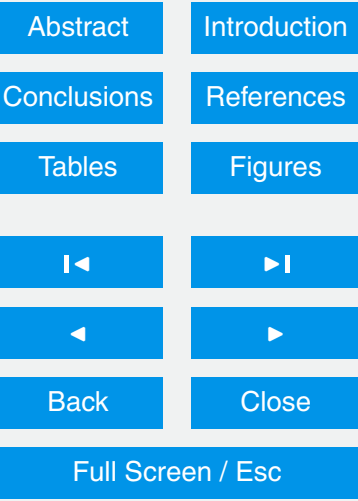

Printer-friendly Version

Interactive Discussion 
remain to be studied and this has been highlighted by IPCC (Kirtman et al., 2013) as an area that is poorly understood. Improvement of representation of processes that lead to ammonia emission in atmospheric models has therefore frequently been highlighted as an area that needs scientific attention (Flechard et al., 2013; Sutton et al., 2013).

Ammonia emission inventories for regional air-quality models in Europe have mainly been based on a bottom-up approach, where activity statistics are combined with standard emission factors to estimate annual emissions. The temporal variation is typically included as a standardised seasonal variation with a monthly profile (Schaap et al., 2005). Recently, Sutton et al. (2013) suggested two long-term goals on ammonia mod10 elling within CTMs. Firstly, the same meteorological data should be used to drive the emission, the chemistry-transport and the bi-directional exchange. Secondly, the emission should be calculated online in the CTM's whereby the feedbacks between the ammonia emissions and climate can be included. Recently, Zhu et al. (2015) indicated that updates to the governing processes on both dynamics and physics concerning $\mathrm{NH}_{3}$ 15 need improvements. Previous studies have shown significant improvements in model performance by replacing static seasonal variations by a dynamic approach which accounts for physical processes like volatilization of $\mathrm{NH}_{3}$ (Skjøth et al., 2011). Similarly, other modelling studies have shown that some atmospheric components are sensitive to the formulation of the ammonia emission (Gilliland et al., 2003). This highlights the need for a better understanding of ammonia emissions and how this is implemented in CTM models. Results presented by Werner et al. (2015) suggest that implementing this dynamical approach improves simulations even in areas with limited information about location of the agricultural fields, livestock and agricultural production methods.

Recent studies on modelling atmospheric ammonia with CTMs have focused on the 25 implementation of the bidirectional $\mathrm{NH}_{3}$ exchange between atmosphere and surface (Bash et al., 2013; Wichink Kruit et al., 2012; Zhu et al., 2015), impact of ammonia emissions on concentrations of secondary inorganic aerosols (Banzhaf et al., 2013; Bessagnet et al., 2014; Hamaoui-Laguel et al., 2014), investigations of the role of different natural emission sources of ammonia (Hansen et al., 2013; Riddick et al., 2014)

\section{ACPD}

15, 22935-22973, 2015

$\mathrm{NH}_{3}$ concentrations

over Europe - a static and dynamic approach with WRF-Chem

M. Werner et al.

\section{Title Page}

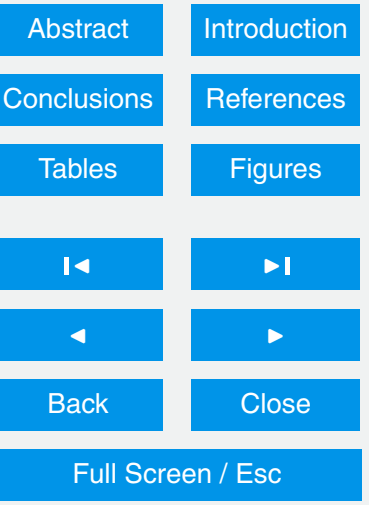

Printer-friendly Version

Interactive Discussion 
and improvements in the representation of ammonia emission from different agricultural activities, e.g. livestock emission (Zhu et al., 2015) and mineral fertilizers (HamaouiLaguel, 2014). Focus on the processes that generate ammonia emissions and the initial dispersion has however had limited attention in the development of existing CTM 5 models. Addressing this knowledge gap is one of the objectives in the FP7 project ECLAIRE (Sutton et al., 2013).

In our study we aim at improving the basic understanding of ammonia in the atmosphere. We will also identify current limitations in relation to the governing processes that cause ammonia emissions and initial dispersion due to meteorological parameters.

10 For this purpose we have implemented the emission from a dynamical ammonia emission model into WRF-Chem and evaluated the model results against a commonly used static approach for describing the emissions. To reveal the limitations in descriptions of the processes, we analyse and compare the model results against hourly observations from one station and daily observations from six stations during the year 2012 .

15 The sites have been chosen because they are all located in areas under the influence of agricultural activities. For selected episodes in February, April, July and October, we have analysed both the vertical and temporal development of ammonia concentrations in order to highlight the governing processes that are responsible for initial distribution of ammonia concentrations using meteograms. This analysis of ammonia concentrations both vertically and temporally has not been undertaken before with regional scale atmospheric models. This therefore represents a substantial step forward in understanding the behaviour of ammonia in the atmosphere.

\section{Data and methods}

\subsection{WRF-Chem model}

25 The Weather Research and Forecasting model coupled online with chemistry (WRFChem) was used to simulate the meteorological conditions and ammonia concentra-

\section{ACPD}

15, 22935-22973, 2015

$\mathrm{NH}_{3}$ concentrations

over Europe - a static and dynamic approach with WRF-Chem

M. Werner et al.

\section{Title Page}

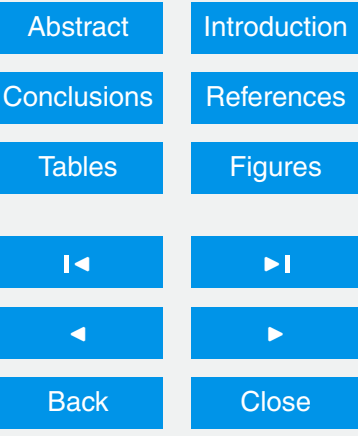

Full Screen / Esc

Printer-friendly Version

Interactive Discussion 
tions over Europe for the entire year 2012. A complete description of the model is given by Grell et al. (2005) and Fast et al. (2006). The GFS FNL global analysis, created and maintained by the National Centre for Environmental Prediction (NCEP), with a spatial resolution of $1^{\circ} \times 1^{\circ}$ (longitude-latitude) and a vertical resolution of 27 pressure lev5 els, were used to define the initial and boundary meteorological conditions. The main setup and the physical and chemical schemes used in this study are listed in Table 1. The last five days of the year 2011 were used as a spin up for the chemistry as in Forkel et al. (2014). We used the RADM2 gas phase chemistry (Stockwell et al., 1990) and the MADE/SORGAM aerosol module (Ackermann et al., 1998; Schell et al., 2001) 10 with the aerosol direct and indirect radiative effect included (Forkel et al., 2012; Werner et al., 2015). Chemistry transport modelling in general benefits from a high number of layers within the Planetary Boundary Layer (PBL) (Zhang et al., 2010), especially near the surface, when calculations concern gases with a fast deposition velocity, like e.g. ammonia (Ellis et al., 2011). Thus, we adjusted the vertical resolution in WRF-Chem by 5 decreasing the thickness of the lowest layer from 53 to $20 \mathrm{~m}$ and doubling the number of layers within the first $1015 \mathrm{~m}$, which gives 48 layers in total.

The WRF-Chem model has been extensively used and evaluated for both meteorological and air quality studies in Europe. The model performance for meteorology affects both the air quality results and the calculated emissions. Several studies, focused on the entire Europe, report biases for both air temperature and precipitation, e.g. Miglietta et al. (2012), Katragkou et al. (2015), Wałaszek et al. (2014), Kim et al. (2013), Warrach-Sagi et al. (2013). Recent findings provided by Skjøth et al. (2015) show that the bias in air temperature at $2 \mathrm{~m}$ varies spatially and seasonally. These biases are significant and might affect e.g. online calculated emissions and the processes in vegetation models. Similar findings are reported by Kryza et al. (2015) for the area of Poland, where the air temperature bias is low in winter, but summer temperatures are significantly overestimated. A bias in WRF calculated air temperatures were also reported by Mooney et al. (2013) and Miglietta et al. (2012). The model performs well at simulating wind speed (Jiménez and Dudhia, 2013; Miglietta et al., 2012; Santos-Alamillos et al.,

\section{ACPD}

15, 22935-22973, 2015

$\mathrm{NH}_{3}$ concentrations

over Europe - a static and dynamic approach with WRF-Chem

M. Werner et al.

\section{Title Page}

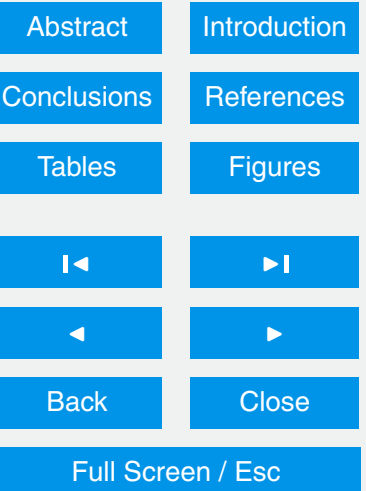

Printer-friendly Version

Interactive Discussion 
2013; Vieno et al., 2010) which is the second variable affecting ammonia emission in this study.

The WRF-Chem model was run twice in our study. In the first simulation we ran WRFChem using the TNO MACC II emission data set with $1 / 8^{\circ} \times 1 / 16^{\circ}$ spatial resolution 5 (Kuenen et al., 2014) and a temporal emission profile commonly used for the temporal disaggregation in ammonia emissions in current CTMs (Schaap et al., 2005). It includes a seasonal variation that changes each month, but the seasonal variation is the same throughout the entire model domain. This simulation is subsequently referred to as "BASE". In the second simulation we ran the WRF-Chem model with hourly variations

10 in ammonia emissions for the entire year 2012 by using the same approach as for the Danish Eulerian Hemispheric Model (Geels et al., 2012), where the ammonia emission model uses gridded hourly meteorology (calculated with WRF-Chem) to simulate the hourly emission variations (a description of the dynamic model is given in the following section). This simulation is in the following referred to as "DYNAMIC".

\subsection{Dynamic emission model}

The fundamentals of the dynamic emission model are provided by Gyldenkærne et al. (2005), Skjøth et al. $(2004,2011)$. The model code is freely available and flexible for use with respect to geographical area and underlying assumptions (Skjøth et al., 2011). The general idea behind the emission model is to use the gridded annual total $\mathrm{NH}_{3}$ emissions, in this study the TNO MACC II (Kuenen et al., 2014), and to use available activity data to make a disaggregation of the gridded annual totals into specific agricultural sectors. The emission from each sector is then simulated with individual parametrizations. The TNO emission was re-gridded to the WRF-Chem grid using a mass conservation approach. The emission from each agricultural sector uses a pa25 rameterisation that depends on both the volatilisation as a function of meteorology and the temporal pattern of activity. The meteorological parameters used in the dynamic model, $2 \mathrm{~m}$ temperature and $10 \mathrm{~m}$ wind speed, were calculated with WRF-Chem with $1 \mathrm{~h}$ temporal resolution and with $36 \mathrm{~km} \times 36 \mathrm{~km}$ spatial resolution. The emission parame-

$\mathrm{NH}_{3}$ concentrations

over Europe - a static and dynamic approach with WRF-Chem

M. Werner et al.

\section{Title Page}

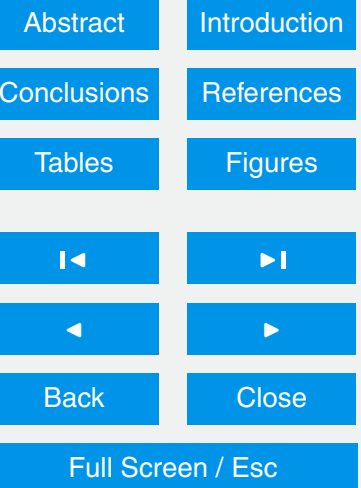

Printer-friendly Version

Interactive Discussion 
terization consists of 16 additive continuous functions, describing emission from animal houses and storage (3 functions), application of manure and mineral fertilizer ( 7 functions), emission from crops (4 functions), grazing animals, and ammonia treatment of straw, respectively. Several of the underlying studies for producing parameterizations, 5 such as the applied growth model (Olesen and Plauborg, 1995) and the farm surveys by Seedorf et al. (1998a, b), are based on Europe-wide studies and are considered appropriate for large geographical regions (Skjøth et al., 2011).

\subsection{Model evaluation}

The focus in this study is on improved understanding of short term variations of ammonia and the impact from agricultural emission sources. Only one site in the EMEP network - Harwell (UK) provided hourly ammonia data from an agricultural region for the year 2012. Additionally, we used all available daily ammonia concentration measurements for 2012 from sites located near the agricultural sources. These sites were: Jarczew (Poland) - data were provided by the Chief Inspectorate of Environmental Protection in Poland and gathered within the State Environmental Monitoring programme and four Danish stations (Risø, Tange, Ulborg and Anholt) that are part of the Danish Background Air Quality Monitoring Program. Thus, we were able to evaluate the model results for remote geographical areas that differ in terms of climate conditions and agriculture practice.

20 The $\mathrm{NH}_{3}$ and $\mathrm{NH}_{4}^{+}$ambient air concentrations were measured using the filter pack method for all the Danish sites and the Polish site Jarczew. The filter pack method does not give a complete separation of $\mathrm{NH}_{3}$ and $\mathrm{NH}_{4}$ (Skjøth et al., 2004). However, comparisons between filter pack and denuder sampling have demonstrated that for Danish monitoring stations a satisfactory separation can be obtained (Andersen and IC method.

In the model evaluation process, firstly we compared ammonia concentrations from the WRF-Chem model with hourly measurements from Harwell for four seasons (Ta-

ACPD

15, 22935-22973, 2015

$\mathrm{NH}_{3}$ concentrations

over Europe - a static and dynamic approach with WRF-Chem

M. Werner et al.

\section{Title Page}

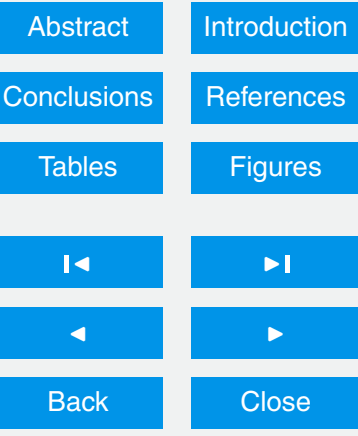

Full Screen / Esc

Printer-friendly Version

Interactive Discussion 
ble 2). The seasons were calculated as follows: winter (January, February and December), spring (March, April and May), summer (June, July and August) and autumn (September, October and November). We also explored the temporal variation of ammonia concentrations with height using meteograms for four selected episodes and 5 compared the surface concentrations with the PBL height. Secondly, we calculated statistics for the entire study period and the six measuring sites using the daily mean $\mathrm{NH}_{3}$ concentrations, both for the BASE and DYNAMIC simulations (Table 3). The following measures were used to summarize the WRF-Chem model performance for both runs: factor of two (FAC2), mean bias (MB), normalized mean bias (NMB), root mean 10 squared error (RMSE) and correlation coefficient $(R)$. We then calculated mean statistics from all stations according to the seasons (Table 4). The number of observations available for each season is listed in Tables 2, 3, and 4 as "n". Finally, we evaluated the spatial pattern in ammonia emission by calculating the day of the year (Julian Day) for which the model estimated the highest hourly ammonia concentrations, with calculation 15 performed independently for each grid cell.

\section{Results}

The results are presented in the following order: (1) temporal pattern of ammonia emission and concentrations including vertical distribution of concentrations, (2) spatial distribution of $\mathrm{NH}_{3}$ concentrations for the BASE and DYNAMIC simulations, (3) compar-

DYNAMIC runs.

\subsection{Temporal and vertical distribution of $\mathrm{NH}_{3}$ emissions and concentrations}

\subsubsection{Hourly ammonia emission and concentration - temporal pattern}

The hourly profiles of ammonia emissions (DYNAMIC approach only) and modelled

\section{ACPD}

15, 22935-22973, 2015

$\mathrm{NH}_{3}$ concentrations

over Europe - a static and dynamic approach with WRF-Chem

M. Werner et al.

\section{Title Page}

14 $\rightarrow \mathbf{I}$

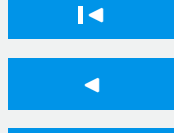

Back 
the Harwell station. These profiles are calculated for each of the four seasons and then normalised for this comparison (Fig. 1). The dynamic approach shows that the emissions typically peak during the afternoon in each case, starting from 1.00 p.m. in the autumn to 3.00 p.m. in the winter and that the minimum is around 6 in the morning, where the difference is up to a factor of two between minimum and maximum. According to the observed values, the highest $\mathrm{NH}_{3}$ concentrations are during the day time, between 9.00 a.m. and 3.00 p.m. Modelled concentration peaks are shifted towards afternoon hours, when compared with measured $\mathrm{NH}_{3}$ concentrations. The lowest concentrations are modelled at midday and highest at night. This pattern is similar for all 10 the seasons considered. For each season, DYNAMIC pattern is slightly closer to measurements than BASE. The closest agreement between the measurements and the DYNAMIC run is for winter. For this season, there is also the largest improvement if the BASE and DYNAMIC runs are compared.

The effect of meteorology on ammonia emissions and concentrations is also high15 lighted with Fig. 2, that shows that the DYNAMIC time series agree better with observations e.g. for the beginning of February and the second part of April. Despite the improvement with the dynamic approach, there is still a significant disagreement on overall peak time between observations and simulations. The plots for July and October reveal that for both BASE and DYNAMIC runs the model is in relatively poor agreement with the hourly $\mathrm{NH}_{3}$ measurements. An example e.g. for the last week of July shows that both the BASE and DYNAMIC simulations generally follow the increased $\mathrm{NH}_{3}$ measured at Harwell, but are not capable of resolving observed diurnal variations.

\subsubsection{Hourly ammonia concentrations - vertical pattern}

The vertical distribution of $\mathrm{NH}_{3}$ concentration has been studied at one location for the 25 have chosen Harwell as it is the only site with available hourly observations. The vertical distribution of ammonia for the BASE and DYNAMIC simulation is similar for all seasons (Figs. 3 and S1). The general pattern indicates that the highest concentra-

\section{ACPD}

15, 22935-22973, 2015

$\mathrm{NH}_{3}$ concentrations

over Europe - a static and dynamic approach with WRF-Chem

M. Werner et al.

\section{Title Page}

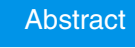

Conclusions

Tables

14 4

Back
Introduction

References

Figures

DI
Close

Full Screen / Esc

Printer-friendly Version

Interactive Discussion

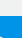


tions are at the surface layer with a linear decrease towards the upper layers. The WRF-Chem model calculates the highest ammonia concentrations at night time, with the time of the maximum varying according to the month. During the periods analysed, this usually occurs before or at midnight in February and July, and after or at midnight 5 in April. In October, the maximum values appear both before and after midnight. In July and October, there are individual days with increased concentrations in the upper layers (4 July and 5 October), which are accompanied by high surface concentrations. The daily pattern of the ammonia concentration is seen to be less regular for some short periods - e.g. on the 5 April, which is related to a precipitation event during that day and 10 washout of ammonia from the atmosphere. For all episodes, ammonia concentration peaks are negatively correlated with the PBL height (Fig. 4). In fact, the periods with the strongest diurnal pattern of ammonia concentrations are also on the days with large differences in PBLH between day and night. For April, we have illustrated the vertical distribution of $\mathrm{NO}_{3}^{-}, \mathrm{NH}_{4}^{+}$and $\mathrm{SO}_{4}^{2}$ - concentrations in the Supplement (Fig. S2). It can 15 be seen that high concentrations of airborne aerosols (Fig. S2), are slightly shifted with a later peak compared to the peak values of ammonia concentrations (aerosol peaks are about $1-2 \mathrm{~h}$ later). These figures also show that the maximum aerosol concentrations appear above the surface layer - for $\mathrm{NO}_{3}^{-}$and $\mathrm{NH}_{4}^{+}$this is usually about $200 \mathrm{~m}$ above ground level.

\subsubsection{Daily ammonia concentrations - temporal pattern}

The time series with observed and modelled (BASE and DYNAMIC) ammonia concentrations are presented for all stations in Fig. 5. The modelled peak of ammonia concentrations starts at the beginning of February for the BASE simulation and is moved towards March and April for the DYNAMIC simulation. This results in a bet-

ter agreement with measurements for each station (Fig. 5). However, the magnitude of this spring time peak is overestimated for all the stations, both for BASE and DYNAMIC. The spring peak is much more extended in time in the BASE simulation, if compared to both the observations and the DYNAMIC simulation. The DYNAMIC simulation pro22945

\section{ACPD}

15, 22935-22973, 2015

$\mathrm{NH}_{3}$ concentrations

over Europe - a static and dynamic approach with WRF-Chem

M. Werner et al.

\section{Title Page}

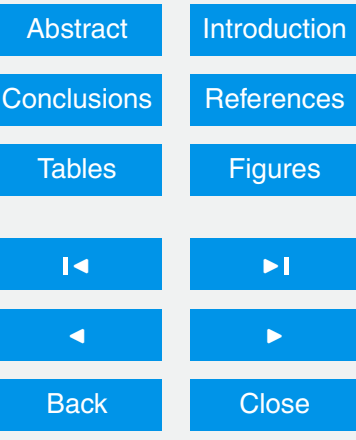

Full Screen / Esc

Printer-friendly Version

Interactive Discussion 
vides a second peak in autumn, which is not present in the observed data for Danish sites and is less pronounced for the BASE simulation.

\subsection{Spatial distribution of $\mathrm{NH}_{3}$ concentrations}

The BASE simulation shows that the highest ammonia concentrations in February are 5 in western France, northern Italy and several regions of Eastern Europe (Fig. 6). The DYNAMIC simulation shows that the maximum values in February are for the same regions, but the $\mathrm{NH}_{3}$ air concentrations are 10 times lower if compared to the BASE simulation. In April, high concentrations with value above $10 \mathrm{\mu g} \mathrm{m}^{-3}$ are found in Germany, France, Denmark, and northern Italy for the BASE simulation. For the DYNAMIC simulation high concentrations cover the entire central Europe. In October, both model runs show similar spatial distribution of $\mathrm{NH}_{3}$ concentrations.

Figure 7 shows the Julian day number (for calendar year 2012), for which the model calculated the highest hourly ammonia concentrations. This was calculated to check whether there is a clear south-north pattern, with increasing number of day towards north for the DYNAMIC simulation and compare this with the results for the BASE simulation. In Central, Eastern and Western Europe, this annual peak day appears later for the DYNAMIC simulation than for the BASE simulation. In the areas with low or no ammonia emissions (e.g. northern Scandinavia) the difference is small between the two simulations. For BASE it is at around day number 60-70 in Central and Eastern Europe, day number 60-90 in Western Europe and above day number 190 in Scandinavian Peninsula. The DYNAMIC simulation shows day number 100-120, day number 70-90, and above day number 190, respectively. Spring application of manure and fertilizers (day number 90-120) described in the DYNAMIC simulation is responsible for the maximum ammonia concentrations in most of the European countries with high
ACPD

15, 22935-22973, 2015

$\mathrm{NH}_{3}$ concentrations

over Europe - a static and dynamic approach with WRF-Chem

M. Werner et al.

\section{Title Page}

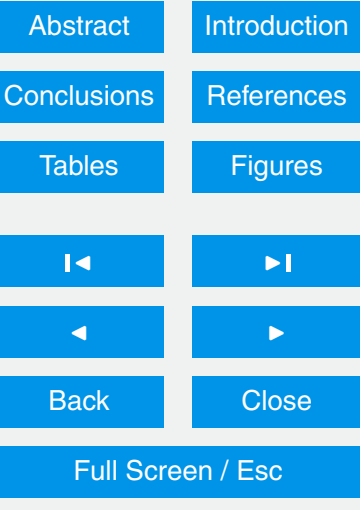

Printer-friendly Version

Interactive Discussion 


\subsection{Model evaluation for the BASE and DYNAMIC simulation}

Comparison of modelled and measured hourly $\mathrm{NH}_{3}$ concentrations for Harwell for the BASE simulation indicates the lowest NMGE and the highest $R$ for spring (Table 2). The lowest performance according to NMGE and $R$ is for autumn and summer, respectively.

5 For the DYNAMIC simulation all statistics are improved, in comparison to BASE, for the winter and autumn season. The only exception here is $R$ for autumn, which slightly decreases for the DYNAMIC approach.

Mean statistics, based on daily values from 6 stations (Harwell, Jarczew, Risø, Tange, Ulborg and Anholt) for 2012, indicate generally better performance (higher FAC2 and 10 $R$ and lower bias) for the DYNAMIC simulation than for BASE (Table 3). FAC2 and $R$ increase moving from BASE to DYNAMIC for winter, spring and summer and bias and error measures are improved for winter and spring (Table 4). The most significant improvement is for the winter season, whereas the smallest changes are for summer. The DYNAMIC simulation has a larger positive bias than the BASE simulation during 15 spring.

A general pattern of the differences between BASE and DYNAMIC, described above, is present at all the individual sites (Fig. 8). The BASE simulation significantly overestimates the measured ammonia concentration for winter, which is improved for the DYNAMIC simulation (RMSE decreases for all stations, Fig. 8). An improvement in correlation coefficient between BASE and DYNAMIC for Harwell, Jarczew and Tange is accompanied by an increase of the RMSE. The highest decrease in the model performance between BASE and DYNAMIC is for autumn for Danish sites.

\section{Discussion and conclusion}

We have observed an improvement for the DYNAMIC approach for the winter and autumn seasons but for the entire year the modelled hourly ammonia peaks are shifted toward the afternoon hours if compared with measurements. This occurs both for the
ACPD

15, 22935-22973, 2015

$\mathrm{NH}_{3}$ concentrations

over Europe - a static and dynamic approach with WRF-Chem

M. Werner et al.

\section{Title Page}

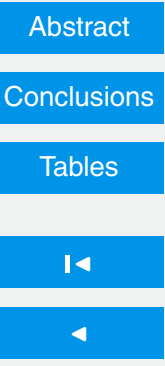

Introduction

References

\section{Figures}

\section{$\rightarrow 1$}


BASE and DYNAMIC simulation, despite a strong peak of emission in mid-day for the DYNAMIC approach. Analysis of the vertical distribution of modelled ammonia concentrations indicates that the main source of ammonia in the air is from the surface, as the highest concentrations are close to the ground and decrease linearly with height. 5 Moreover, the maximum aerosol concentration appears after the peak of $\mathrm{NH}_{3}$ concentration, which infers that the ammonia peaks are not related to release of ammonia from aerosols. A similar modelled ammonia concentration pattern to that described above was reported by Wen et al. (2014) for STILT-Chem simulations over southern Ontario in the US, with the limitation that the results were not evaluated against observations. 10 Studies presented by Pinder et al. (2006) for the US emphasise that diurnal profile of ammonia emission is especially important for accurately predicting the concentrations at night, since the decreased atmospheric mixing makes the night especially sensitive to emission changes. Without diurnal variation in the emission, the model overestimates the concentrations at night, which leads to a bias in the average ammonia and 15 ammonium concentration. Pinder et al. (2006) compared the model against mean daily observations and found that in January and July, the seasonally varied inventories significantly improve the predictions of $\mathrm{NH}_{3}$ and $\mathrm{NH}_{4}^{+}$concentrations. Our study confirms this improvement for the winter season, for which there is an increase e.g. in correlation coefficient or decrease of bias for all four stations representing different geographical areas and climatological conditions. In our investigation however we go a step further by analysing the hourly and vertical ammonia pattern, and found that there is still an unresolved problem with a discrepancy in time of peaks of the ammonia concentration between modelled and measured concentrations.

We have observed that for each analysed episode (March, April, July and October), 25 the surface ammonia concentrations are anti-correlated with the planetary boundary layer height - midday peaks of PBLH are accompanied by a local minimum of $\mathrm{NH}_{3}$ concentrations. It has been previously shown that PBLH is an important variable for air quality modelling, which is often difficult to simulate accurately in numerical models (Dabberdt et al., 2004; Hu et al., 2010b; Xie et al., 2012). Determining the PBLH is

\section{ACPD}

15, 22935-22973, 2015

$\mathrm{NH}_{3}$ concentrations

over Europe - a static and dynamic approach with WRF-Chem

M. Werner et al.

\section{Title Page}

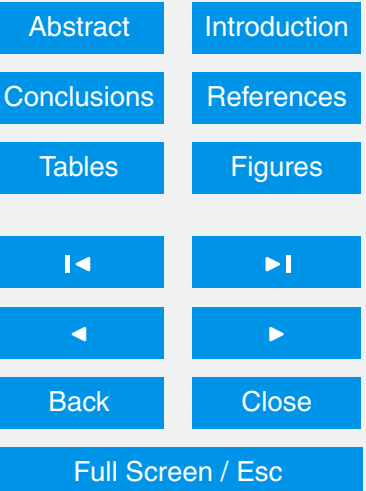

Printer-friendly Version

Interactive Discussion 
important in atmospheric numerical models, because it is used in other physical parameterisations and because it is a governing parameter for the distribution of trace gases (Geels et al., 2007). Meteorological conditions are known to exert a direct impact on the air quality simulation. Han et al. (2008) showed that the difference in modelled vertical 5 turbulent mixing is one of the main reasons for the discrepancy in pollutant concentration among the chemical transport models. The purpose of a PBL parametrization is to redistribute energy and humidity in the PBL. Both humidity and temperature have an impact on ammonia concentrations. Previous studies suggest that the YSU scheme in WRF (Hong et al., 2006), which was also applied in our study, tends to overestimate 10 the PBL height (Hu et al., 2010a; Xie et al., 2012). The highest variability between measurements and modelled data are in the midday and are rather constant at night (Ács et al., 2014). Kim et al. (2013) have found that the YSU and MYJ schemes in WRF overestimate, while the ACM2 and MYNN underestimate the PBL height. Their study over Greater Paris indicates that the modelled mean PBLH differs significantly among 15 the schemes and by more than $300 \%$ between the MYNN and YSU. Overestimation of PBLH in chemical transport models, like e.g. WRF-Chem might cause an overestimation of mixing layer depth and result in an underestimation of modelled pollution concentrations. The latter might be especially relevant for emissions that are released from the surface. Based on the meteograms plotted here, we suggest that the vertical extent of the PBL will directly impact the overall concentration of ammonia in the PBL layer. The PBL physics - and therefore also the choice of parametrisation - must therefore affect the ammonia concentrations both at the surface as well as throughout the PBL layer.

The potential higher bias in T2 from the WRF model, reported for Central Europe for 25 summer season by e.g. Skjøth et al. (2015) and Kryza et al. (2015) will impact the modelled ammonia concentrations. The Jarczew station, located in this region reveals an increased bias in ammonia concentration for the DYNAMIC simulation in comparison to the BASE simulation during the summer season. However, this increased bias for the DYNAMIC simulation is also present for the spring season. This suggests that the

\section{ACPD}

15, 22935-22973, 2015

$\mathrm{NH}_{3}$ concentrations

over Europe - a static and dynamic approach with WRF-Chem

M. Werner et al.

\section{Title Page}

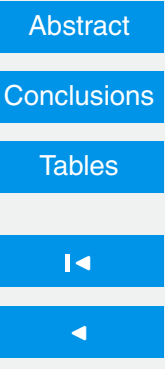

Introduction

References

Figures

>I

$>$

Back

Close

Full Screen / Esc

Printer-friendly Version

Interactive Discussion 
bias in ammonia concentrations is not related to a bias in temperatures that is mainly seen during summer. Most likely the reason is a combination of a too coarse grid in WRF-Chem and how the ammonia emission is distributed between different emission sectors implemented into the dynamic emission model, which are then affected by the 5 meteorological factors. Several studies showed that significant differences may occur between measured and modelled ammonia concentrations due to the grid size resolution. Especially, the highly localized nature of $\mathrm{NH}_{3}$ emissions is causing this difference (Dore et al., 2007; Van Pul et al., 2009).

Overall, the results suggest the disagreements between the model and the obser10 vations in the hourly profiles are mainly related to emission of ammonia and dilution processes (e.g. increased PBL height and chemical conversion). The results with the aerosols suggest that the high night-time concentrations are not due to release of ammonia from nitrogen containing aerosols. The most likely cause of these high concentrations is that the flux of ammonia from the surface is too high during the night time. 15 The flux of ammonia from agricultural sources away from the surface is mainly dependent on two processes - direct emission due to volatilization (e.g. higher temperatures give higher emission) and the effect of turbulence. The parametrisation we have used does not provide an increase of $100 \%$ in emission from manure that is applied to the field as it is directly linked to previous studies with the ALFAM model (Gyldenkærne et al., 2005; Skjøth et al., 2004) and the parameterisation does not take into account turbulence at the surface but instead uses wind speed data from the ALFAM model (Skjøth et al., 2004). The combination of the temperature and wind speed effect has the consequence that there will be a continuous release of ammonia during night-time even during low temperatures and low wind speeds. Therefore, it must be expected that this limitation causes a redistribution of emission from day to night-time thereby reducing the diurnal emission profile causing a lower daytime peak. If this hypothesis is correct, then new field experiments as a replacement of older experimental data from the ALFAM would be appropriate. Such observations could be used to update the ef-

\section{ACPD}

15, 22935-22973, 2015

$\mathrm{NH}_{3}$ concentrations

over Europe - a static and dynamic approach with WRF-Chem

M. Werner et al.

\section{Title Page}

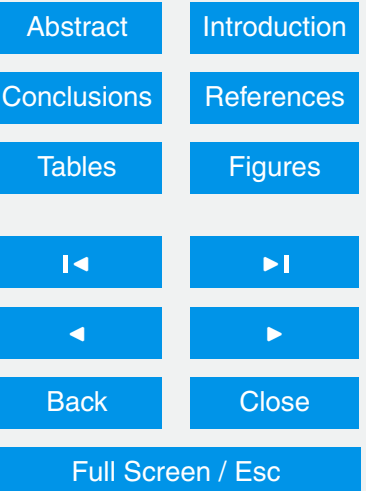

Printer-friendly Version

Interactive Discussion 
fect of environmental parameters on the volatilization of ammonia from fields within the emission model.

Application of the dynamic ammonia emission into the WRF-Chem model results in the improvement of modelled daily ammonia concentrations in comparison to the 5 static approach, which is currently widely used in CTMs. All mean annual statistics based on daily values taken from all the stations have improved when moving from the BASE to the DYNAMIC approach. The smallest differences between both simulations are seen during the summer period, which is likely due to the fact that e.g. the application of manure or fertilizers is limited during this period. For other periods the changes 10 are significant. Due to the implementation of the meteorological conditions in the DYNAMIC approach, a significant proportion of the emission was moved from the winter period to spring, giving much better model performance for winter and a more reliable pattern of daily ammonia concentrations for spring. However, the spring modelled concentrations are overestimated, which most likely can be improved by replacing the

15 Europe-wide default setting, used here after Skjøth et al. (2011) with national practice and regulations for individual countries, as suggested by Werner et al. (2015). Studies of the negative effects related to high ammonia have shown that the plants sensitivity to ammonia might depend on the evolution of the plants and hence can vary throughout the seasons (Sheppard et al., 2009). If CTMs are going to be used for environmental assessments that focus on the seasonal and also the short term variations of ammonia, then it is recommended to adjust the Europe-scale settings in the model with nation-scale settings over the target areas.

The spatial distribution of ammonia emission varies substantially between the BASE and DYNAMIC simulations. This difference is especially noticed for countries with high 25 ammonia emissions. High ammonia concentrations (above $10 \mu \mathrm{g} \mathrm{m}^{-3}$ ) occur during the winter period obtained with the BASE simulation for northern Italy, northern France, Germany and Poland. These high concentrations are caused by both emissions (higher than in the DYNAMIC simulation) and meteorological conditions, such as low PBL height that decrease dilution and low temperatures that decrease chemical conver-

ACPD

15, 22935-22973, 2015

$\mathrm{NH}_{3}$ concentrations

over Europe - a static and dynamic approach with WRF-Chem

M. Werner et al.

\section{Title Page}

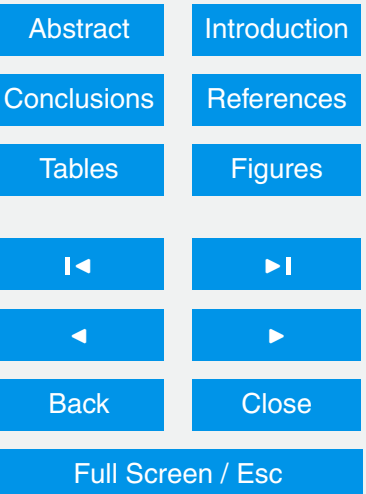

Printer-friendly Version

Interactive Discussion 
sion. In April, for the same areas, much higher concentrations are modelled with the DYNAMIC simulation than with the BASE simulation. This is related to high ammonia emissions during that period caused by application of manure and fertilizers in growing crops. Simultaneously for April, the DYNAMIC simulation calculated the highest ammo5 nia concentrations for many European regions, presented in this study as the number of day with the highest hourly concentrations. Similar findings on spatial variability were also documented by Hamaoui-Laguel et al. (2014), for a study conducted over France. Their study focused on the effect of emission from mineral fertilizers and these results showed that the spatial pattern was highly dependent on actual meteorological condi10 tions. These results using the CHIMERE model, the results by Wen et al. (2014) with STILT-Chem, our results with WRF-Chem as well as previous studies with this emission model all suggest that it is important to have a direct connection between hourly meteorological variables and the level of ammonia emission.

Our study does not include bi-directional exchange, which can further influence the 15 modelled ammonia concentrations. Recent study provided by Zhu et al. (2015) suggests that although the implementation of bi-directional exchange leads to a better fundamental description of $\mathrm{NH}_{3}$ emissions from fertilizers, it does not uniformly improve estimation of $\mathrm{NH}_{3}$ concentrations, $\mathrm{NH}_{4}^{+}$wet deposition and nitrate aerosol concentrations. However, Bash et al. (2013) reported that an implementation of bi-directional exchange of $\mathrm{NH}_{3}$ improved the simulations of $\mathrm{NH}_{x}$ wet deposition and improved the simulation of ambient nitrate aerosol concentrations for the US. Wichink Kruit et al. (2012) showed that with the new description in the LOTOS-EUROS model, which includes bi-directional surface-atmosphere exchange, the modelled ammonia concentrations increase almost everywhere, in particular in agricultural source areas. The reason for this is that by using a compensation point the ammonia lifetime and transport distance is increased. A comparison with measurements shows that the model results better represent measured ammonia concentrations; however the concentrations in nature areas are slightly overestimated, while the concentrations in agricultural sources are underestimated.

\section{ACPD}

15, 22935-22973, 2015

$\mathrm{NH}_{3}$ concentrations

over Europe - a static and dynamic approach with WRF-Chem

M. Werner et al.

\section{Title Page}

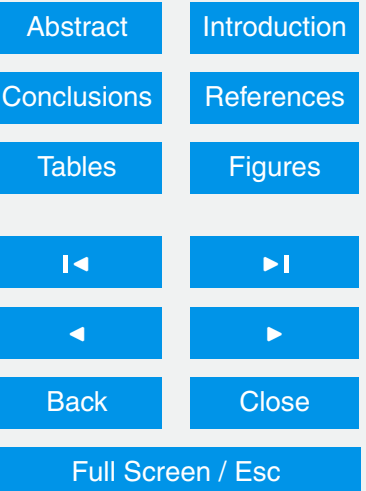

Printer-friendly Version

Interactive Discussion 
Our study indicates that the current description of the diurnal cycle of the ammonia concentration from fields is not sufficiently accurate and more research is needed in order to improve the processes that describe the emission from fields. The results suggest that the governing processes in relation to the diurnal cycle are the atmospheric 5 mixing and the stronger daily pattern of ammonia emission, e.g. through increased evaporation or increased fluxes from the surface. The latter is still quite difficult to observe as only very few sites measure ammonia concentrations with a sufficiently high temporal resolution to that required for a proper evaluation and developments of better emissions models. New field experiments as a replacement of older experimental data - would be appropriate in order to update an observational assessment of the emission process parameterised in the model. This is one of the objectives of the ECLAIRE project.

\section{The Supplement related to this article is available online at doi:10.5194/acpd-15-22935-2015-supplement.}

15 Acknowledgements. This study has received support from the EU project ECLAIRE (project no. 282910), the Polish National Science Centre through project no. UMO-2013/09/B/ST10/00594, the Danish Strategic Research Council project ECOCLIM (no. 10-093901) and the SUPREME project from the Danish Research Council (no. 0602-02550B) and the European Commission (no. CIG631745). Additional support was provided through intramural funding by the participat20 ing institutes.

\section{References}

Ackermann, I. J., Hass, H., Memmesheimer, M., Ebel, A., Binkowski, F. S., and Shankar, U.: Modal aerosol dynamics model for Europe, Atmos. Environ., 32, 2981-2999, doi:10.1016/S1352-2310(98)00006-5, 1998.
ACPD

15, 22935-22973, 2015

$\mathrm{NH}_{3}$ concentrations

over Europe - a static and dynamic approach with WRF-Chem

M. Werner et al.

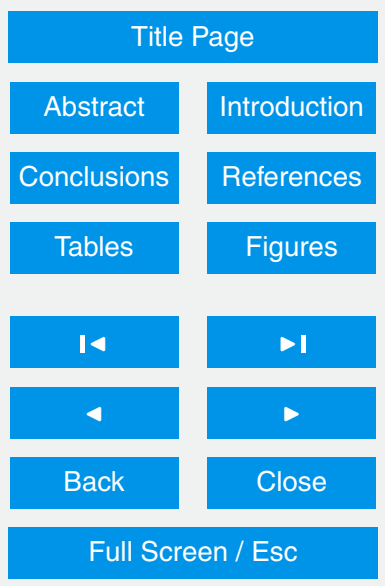

Printer-friendly Version

Interactive Discussion 
Ács, F., Gyöngyösi, A. Z., Breuer, H., Horváth, Á., and Mona, T.: Sensitivity of WRF-simulated planetary boundary layer height to land cover and soil changes, Meteorol. Z., 23, 279-293, doi:10.1127/0941-2948/2014/0544, 2014.

Andersen, H. V. and Hovmand, M. F.: Measurements of ammonia and ammonium by denuder and filter pack, Atmos. Environ., 28, 3495-3512, doi:10.1016/1352-2310(94)90007-8, 1994.

Banzhaf, S., Schaap, M., Wichink Kruit, R. J., Denier van der Gon, H. A. C., Stern, R., and Builtjes, P. J. H.: Impact of emission changes on secondary inorganic aerosol episodes across Germany, Atmos. Chem. Phys., 13, 11675-11693, doi:10.5194/acp-13-11675-2013, 2013.

Bash, J. O., Cooter, E. J., Dennis, R. L., Walker, J. T., and Pleim, J. E.: Evaluation of a regional air-quality model with bidirectional $\mathrm{NH}_{3}$ exchange coupled to an agroecosystem model, Biogeosciences, 10, 1635-1645, doi:10.5194/bg-10-1635-2013, 2013.

Behera, S. N., Sharma, M., Aneja, V. P., and Balasubramanian, R.: Ammonia in the atmosphere: a review on emission sources, atmospheric chemistry and deposition on terrestrial bodies, Environ. Sci. Pollut. R., 20, 8092-8131, doi:10.1007/s11356-013-2051-9, 2013.

Bessagnet, B., Beauchamp, M., Guerreiro, C., de Leeuw, F., Tsyro, S., Colette, A., Meleux, F., Rouill, L., Ruyssenaars, P., Sauter, F., Velders, G. J. M., Foltescu, V. L., and van Aardenne, J.: Can further mitigation of ammonia emissions reduce exceedances of particulate matter air quality standards?, Environ. Sci. Policy, 44, 149-163, doi:10.1016/j.envsci.2014.07.011, 2014.

Bobbink, R., Hicks, K., Galloway, J., Spranger, T., Alkemade, R., Ashmore, M., Bustamante, M., Cinderby, S., Davidson, E., Dentener, F., Emmett, B., Erisman, J.-W., Fenn, M., Gilliam, F., Nordin, A., Pardo, L., and De Vries, W.: Global assessment of nitrogen deposition effects on terrestrial plant diversity: a synthesis, Ecol. Appl., 20, 30-59, doi:10.1890/08-1140.1, 2010.

Bouwman, A. F., Lee, D. S., Asman, W. A. H., Dentener, F. J., Van Der Hoek, K. W., and Olivier, J. G. J.: A global high-resolution emission inventory for ammonia, Global Biogeochem. Cy., 11, 561-587, doi:10.1029/97GB02266, 1997.

Brandt, J., Silver, J. D., Christensen, J. H., Andersen, M. S., Bønløkke, J. H., Sigsgaard, T., Geels, C., Gross, A., Hansen, A. B., Hansen, K. M., Hedegaard, G. B., Kaas, E., and Frohn, L. M.: Contribution from the ten major emission sectors in Europe and Denmark to modelling approach, Atmos. Chem. Phys., 13, 7725-7746, doi:10.5194/acp-13-7725-2013, 2013.

\section{ACPD}

15, 22935-22973, 2015

$\mathrm{NH}_{3}$ concentrations

over Europe - a static and dynamic approach with WRF-Chem

M. Werner et al.

\section{Title Page}

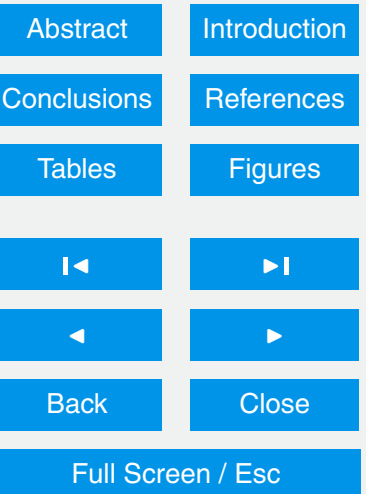

Printer-friendly Version

Interactive Discussion 
Dabberdt, W. F., Carroll, M. A., Baumgardner, D., Carmichael, G., Cohen, R., Dye, T., Ellis, J., Grell, G., Grimmond, S., Hanna, S., Irwin, J., Lamb, B., Madronich, S., McQueen, J., Meagher, J., Odman, T., Pleim, J., Schmid, H. P., and Westphal, D. L.: Meteorological research needs for improved air quality forecasting: report of the 11th Prospectus Development Team of the U.S. Weather Research Program, B. Am. Meteorol. Soc., 85, 563-586, doi:10.1175/BAMS-85-4-563, 2004.

Ellis, R. A., Murphy, J. G., Markovic, M. Z., VandenBoer, T. C., Makar, P. A., Brook, J., and Mihele, C.: The influence of gas-particle partitioning and surface-atmosphere exchange on ammonia during BAQS-Met, Atmos. Chem. Phys., 11, 133-145, doi:10.5194/acp-11-1332011, 2011.

Erisman, J. W., Sutton, M. A., Galloway, J., Klimont, Z., and Winiwarter, W.: How a century of ammonia synthesis changed the world, Nat. Geosci., 1, 636-639, doi:10.1038/ngeo325, 2008.

Fast, J. D., Gustafson, W. I., Easter, R. C., Zaveri, R. A., Barnard, J. C., Chapman, E. G., Grell, G. A., and Peckham, S. E.: Evolution of ozone, particulates, and aerosol direct radiative forcing in the vicinity of Houston using a fully coupled meteorology-chemistry-aerosol model, J. Geophys. Res., 111, D21305, doi:10.1029/2005JD006721, 2006.

Flechard, C. R., Massad, R.-S., Loubet, B., Personne, E., Simpson, D., Bash, J. O., Cooter, E. J., Nemitz, E., and Sutton, M. A.: Advances in understanding, models and parameterizations of biosphere-atmosphere ammonia exchange, Biogeosciences, 10, 5183-5225, doi:10.5194/bg-10-5183-2013, 2013.

Forkel, R., Werhahn, J., Hansen, A. B., McKeen, S., Peckham, S., Grell, G., and Suppan, P.: Effect of aerosol-radiation feedback on regional air quality - a case study with WRF/Chem, Atmos. Environ., 53, 202-211, doi:10.1016/j.atmosenv.2011.10.009, 2012.

Forkel, R., Balzarini, A., Baró, R., Bianconi, R., Curci, G., Jiménez-Guerrero, P., Hirtl, M., Honzak, L., Lorenz, C., Im, U., Pérez, J. L., Pirovano, G., San José, R., Tuccella, P., Werhahn, J., and Žabkar, R.: Analysis of the WRF-Chem contributions to AQMEII phase2 with respect to aerosol radiative feedbacks on meteorology and pollutant distributions, Atmos. Environ., 115, 1-16, doi:10.1016/j.atmosenv.2014.10.056, 2014.

30 Geels, C., Gloor, M., Ciais, P., Bousquet, P., Peylin, P., Vermeulen, A. T., Dargaville, R., Aalto, T., Brandt, J., Christensen, J. H., Frohn, L. M., Haszpra, L., Karstens, U., Rödenbeck, C., Ramonet, M., Carboni, G., and Santaguida, R.: Comparing atmospheric transport models for

\section{ACPD}

15, 22935-22973, 2015

$\mathrm{NH}_{3}$ concentrations

over Europe - a static and dynamic

approach with

WRF-Chem

M. Werner et al.

\section{Title Page}

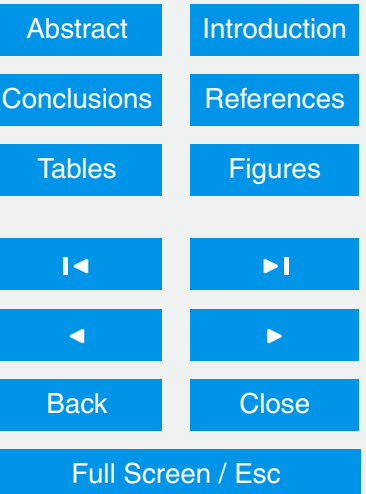

Printer-friendly Version

Interactive Discussion 
future regional inversions over Europe - Part 1: mapping the atmospheric $\mathrm{CO}_{2}$ signals, Atmos. Chem. Phys., 7, 3461-3479, doi:10.5194/acp-7-3461-2007, 2007.

Geels, C., Andersen, H. V., Ambelas Skjøth, C., Christensen, J. H., Ellermann, T., Løfstrøm, P., Gyldenkærne, S., Brandt, J., Hansen, K. M., Frohn, L. M., and Hertel, O.: Improved mod-

5 elling of atmospheric ammonia over Denmark using the coupled modelling system DAMOS, Biogeosciences, 9, 2625-2647, doi:10.5194/bg-9-2625-2012, 2012.

Gilliland, A. B., Dennis, R. L., Roselle, S. J., and Pierce, T. E.: Seasonal $\mathrm{NH}_{3}$ emission estimates for the eastern United States based on ammonium wet concentrations and an inverse modeling method, J. Geophys. Res., 108, doi:10.1029/2002JD003063, 2003.

10 Grell, G., Peckham, S. E., Schmitz, R., McKeen, Stuart Frost, G., Skamarock, W. C., and Eder, B.: Fully coupled "online" chemistry within the WRF model, Atmos. Environ., 39, 69576975, doi:10.1016/j.atmosenv.2005.04.027, 2005.

Gyldenkærne, S., Skjøth, C. A., Hertel, O., and Ellermann, T.: A dynamical ammonia emission parameterization for use in air pollution models, J. Geophys. Res., 110, D07108, doi:10.1029/2004JD005459, 2005.

Hamaoui-Laguel, L., Meleux, F., Beekmann, M., Bessagnet, B., Génermont, S., Cellier, P., and Létinois, L.: Improving ammonia emissions in air quality modelling for France, Atmos. Environ., 92, 584-595, doi:10.1016/j.atmosenv.2012.08.002, 2014.

Han, Z., Ueda, H., and An, J.: Evaluation and intercomparison of meteorological predictions by five MM5-PBL parameterizations in combination with three land-surface models, Atmos. Environ., 42, 233-249, doi:10.1016/j.atmosenv.2007.09.053, 2008.

Hansen, K., Sørensen, L. L., Hertel, O., Geels, C., Skjøth, C. A., Jensen, B., and Boegh, E.: Ammonia emissions from deciduous forest after leaf fall, Biogeosciences, 10, 4577-4589, doi:10.5194/bg-10-4577-2013, 2013.

Hertel, O., Skjøth, C. A., Reis, S., Bleeker, A., Harrison, R. M., Cape, J. N., Fowler, D., Skiba, U., Simpson, D., Jickells, T., Kulmala, M., Gyldenkærne, S., Sørensen, L. L., Erisman, J. W., and Sutton, M. A.: Governing processes for reactive nitrogen compounds in the European atmosphere, Biogeosciences, 9, 4921-4954, doi:10.5194/bg-9-4921-2012, 2012.

Hong, S.-Y., Noh, Y., and Dudhia, J.: A new vertical diffusion package with an explicit treatment of entrainment processes, Mon. Weather Rev., 134, 2318-2341, doi:10.1175/MWR3199.1, 2006.
ACPD

15, 22935-22973, 2015

$\mathrm{NH}_{3}$ concentrations

over Europe - a static and dynamic

approach with

WRF-Chem

M. Werner et al.

\section{Title Page}

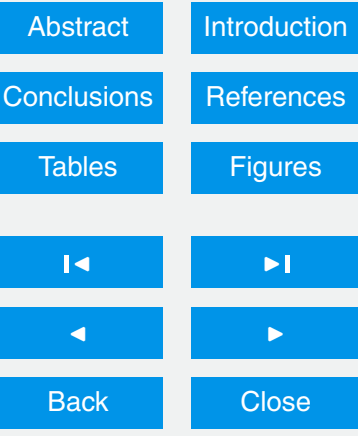

Full Screen / Esc

Printer-friendly Version

Interactive Discussion 
Hu, X. M., Nielsen-Gammon, J. W., and Zhang, F.: Evaluation of three planetary boundary layer schemes in the WRF model, J. Appl. Meteorol. Clim., 49, 1831-1844, doi:10.1175/2010JAMC2432.1, 2010a.

$\mathrm{Hu}$, X.-M., Nielsen-Gammon, J. W., and Zhang, F.: Evaluation of three planetary boundary layer schemes in the WRF model, J. Appl. Meteorol. Clim., 49, 1831-1844, doi:10.1175/2010JAMC2432.1, 2010b.

Jiménez, P. A. and Dudhia, J.: On the ability of the WRF model to reproduce the surface wind direction over complex terrain, J. Appl. Meteorol. Clim., 52, 1610-1617, doi:10.1175/JAMCD-12-0266.1, 2013.

10 Katragkou, E., García-Díez, M., Vautard, R., Sobolowski, S., Zanis, P., Alexandri, G., Cardoso, R. M., Colette, A., Fernandez, J., Gobiet, A., Goergen, K., Karacostas, T., Knist, S., Mayer, S., Soares, P. M. M., Pytharoulis, I., Tegoulias, I., Tsikerdekis, A., and Jacob, D.: Regional climate hindcast simulations within EURO-CORDEX: evaluation of a WRF multiphysics ensemble, Geosci. Model Dev., 8, 603-618, doi:10.5194/gmd-8-603-2015, 2015.

Kim, Y., Sartelet, K., Raut, J. C., and Chazette, P.: Evaluation of the weather research and forecast/urban model over greater Paris, Bound.-Lay. Meteorol., 149, 105-132, doi:10.1007/s10546-013-9838-6, 2013.

Kirtman, B., Power, S. B., Adedoyin, J. A., Boer, G. J., Bojariu, R., Camilloni, I., DoblasReyes, F. J., Fiore, A. M., Kimoto, M., Meehl, G. A., Prather, M., Sarr, A., Schär, C., Sutton, R., Oldenborgh, G. J. van, Vecchi, G., and Wang, H. J.: Near-term climate change: projections and predictability, in: Climate Change 2013: The Physical Science Basis. Contribution of Working Group I to the Fifth Assessment Report of the Intergovernmental Panel on Climate Change, in Contribution of Working Group I to the Fifth Assessment Report of the Intergovernmental Panel on Climate Change, edited by: Stocker, T. F., Qin, D., Plattner, G.K., Tignor, M., Allen, S. K., Boschung, J., Nauels, A., Xia, Y., Bex, V., and Midgley, P. M., Cambridge University Press, Cambridge, UK and New York, NY, USA, p. 76, 2013.

Kryza, M., Wałaszek, K., Ojrzyńska, H., Szymanowski, M., Werner, M., and Dore, A. J.: High resolution dynamical downscaling of ERA-Interim using the WRF regional climate model (Part 1) - model configuration and statistical evaluation for the 1981-2010 period, Pure Appl. Geophys., in review, 2015.

Kuenen, J. J. P., Visschedijk, A. J. H., Jozwicka, M., and Denier van der Gon, H. A. C.: TNO-MACC_II emission inventory; a multi-year (2003-2009) consistent high-resolution Eu-

\section{ACPD}

15, 22935-22973, 2015

$\mathrm{NH}_{3}$ concentrations

over Europe - a static and dynamic

approach with

WRF-Chem

M. Werner et al.

\section{Title Page}

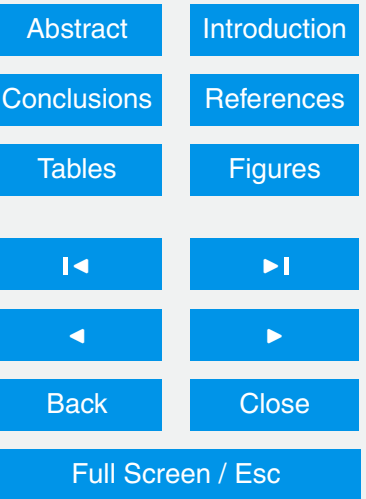

Printer-friendly Version

Interactive Discussion 
ropean emission inventory for air quality modelling, Atmos. Chem. Phys., 14, 10963-10976, doi:10.5194/acp-14-10963-2014, 2014.

Miglietta, M. M., Thunis, P., Georgieva, E., Pederzoli, A., Bessagnet, B., Terrenoire, E., and Colette, A.: Evaluation of WRF model performance in different European regions with the DELTA-FAIRMODE evaluation tool, Int. J. Environ. Pollut., 50, 83-97, 2012.

Monteny, G. J. and Erisman, J. W.: Ammonia emission from dairy cow buildings?: a review of measurement techniques, influencing factors, Neth. J. Agr. Sci., 46, 225-247, 1998.

Mooney, P. A., Mulligan, F. J., and Fealy, R.: Evaluation of the sensitivity of the weather research and forecasting model to parameterization schemes for regional climates of Europe over the period 1990-1995, J. Climate, 26, 1002-1017, doi:10.1175/JCLI-D-11-00676.1, 2013.

Olesen, J. E. and Plauborg, F.: MVTOOL Version 1.10 for Developing MARKVAND, Danish Institute of Plant and Soil Science Science, Research Centre Foulum, 1995.

Pinder, R. W., Adams, P. J., Pandis, S. N., and Gilliland, A. B.: Temporally resolved ammonia emission inventories: current estimates, evaluation tools, and measurement needs, J.

15 Geophys. Res.-Atmos., 111, 1-14, doi:10.1029/2005JD006603, 2006.

Reis, S., Pinder, R. W., Zhang, M., Lijie, G., and Sutton, M. A.: Reactive nitrogen in atmospheric emission inventories, Atmos. Chem. Phys., 9, 7657-7677, doi:10.5194/acp-9-76572009, 2009.

Riddick, S. N., Blackall, T. D., Dragosits, U., Daunt, F., Braban, C. F., Tang, Y. S., MacFarlane, W., Taylor, S., Wanless, S., and Sutton, M. A.: Measurement of ammonia emissions from tropical seabird colonies, Atmos. Environ., 89, 35-42, doi:10.1016/j.atmosenv.2014.02.012, 2014.

Santos-Alamillos, F. J., Pozo-Vázquez, D., Ruiz-Arias, J. A., Lara-Fanego, V., and TovarPescador, J.: Analysis of WRF model wind estimate sensitivity to physics parameterization choice and terrain representation in Andalusia (Southern Spain), J. Appl. Meteorol. Clim., 52, 1592-1609, doi:10.1175/JAMC-D-12-0204.1, 2013.

Schaap, M., Roemer, M., Sauter, F., Boersen, G., Timmermans, R., and Builtjes, P. J. H.: LOTOS-EUROS: Documentation, TNO report B\&O 2005/297, TNO, Apeldoorn, the Netherlands, 2005.

Schell, B., Ackermann, I. J., Hass, H., Binkowski, F. S., and Ebel, A.: Modeling the formation of secondary organic aerosol within a comprehensive air quality model system, J. Geophys. Res.-Atmos., 106, 28275-28293, doi:10.1029/2001JD000384, 2001.

Seedorf, J., Hartung, J., Schröder, M., Linkert, K. H., Pedersen, S., Takai, H., Johnsen, J. O., Metz, J. H. M., Groot Koerkamp, P. W. G., Uenk, G. H., Phillips, V. R., Holden, M. R.,

\section{ACPD}

15, 22935-22973, 2015

$\mathrm{NH}_{3}$ concentrations

over Europe - a static and dynamic

approach with

WRF-Chem

M. Werner et al.

\section{Title Page}

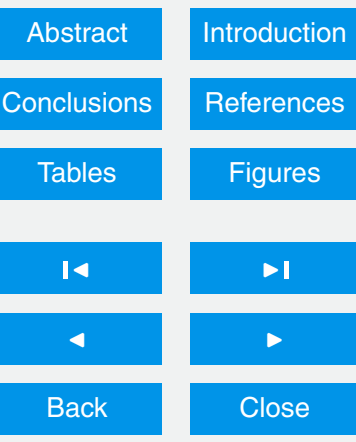

Full Screen / Esc

Printer-friendly Version

Interactive Discussion 
Sneath, R. W., Short, J. L. L., White, R. P., and Wathes, C. M.: A survey of ventilation rates in livestock buildings in Northern Europe, J. Agr. Eng. Res., 70, 39-47, doi:10.1006/jaer.1997.0274, 1998a.

Seedorf, J., Hartung, J., Schröder, M., Linkert, K. H., Pedersen, S., Takai, H., Johnsen, J. O., Metz, J. H. M., Groot Koerkamp, P. W. G., Uenk, G. H., Phillips, V. R., Holden, M. R., Sneath, R. W., Short, J. L., White, R. P., and Wathes, C. M.: Temperature and moisture conditions in livestock buildings in Northern Europe, J. Agr. Eng. Res., 70, 49-57, doi:10.1006/jaer.1997.0284, 1998b.

Sheppard, L. J., Leith, I. D., Crossley, A., Dijk, N. van, Cape, J. N., Fowler, D., and Sutton, M. A.: Long-term cumulative exposure exacerbates the effects of atmospheric ammonia on an ombrotrophic bog: implications for critical levels, in: Atmospheric Ammonia, edited by: Sutton, M. A., Reis, S. and Baker, S. M. H., Springer Netherlands, Dordrecht, 49-58, 2009.

Skjøth, C. A. and Geels, C.: The effect of climate and climate change on ammonia emissions in Europe, Atmos. Chem. Phys., 13, 117-128, doi:10.5194/acp-13-117-2013, 2013.

Skjøth, C. A., Hertel, O., Gyldenkærne, S., and Ellermann, T.: Implementing a dynamical ammonia emission parameterization in the large-scale air pollution model ACDEP, J. Geophys. Res., 109, D06306, doi:10.1029/2003JD003895, 2004.

Skjøth, C. A., Geels, C., Berge, H., Gyldenkærne, S., Fagerli, H., Ellermann, T., Frohn, L. M., Christensen, J., Hansen, K. M., Hansen, K., and Hertel, O.: Spatial and temporal variations in ammonia emissions - a freely accessible model code for Europe, Atmos. Chem. Phys., 11, 5221-5236, doi:10.5194/acp-11-5221-2011, 2011.

Skjøth, C. A., Werner, M., Kryza, M., Adams-Groom, B., Wakeham, A., Lewis, M., and Kennedy, R.: Quality of the governing temperature variables in WRF-Chem in relation to simulation of primary biological aerosols, Adv. Meteorol., http://www.hindawi.com/journals/ amete/aip/412658/, in press, 2015.

Stevens, C. J., Dise, N. B., Mountford, J. O., and Gowing, D. J.: Impact of nitrogen deposition on the species richness of grasslands, Science, 303, 1876-1879, doi:10.1126/science.1094678, 2004.

Stockwell, W. R., Middleton, P., Chang, J. S., and Tang, X.: The second generation regional acid deposition model chemical mechanism for regional air quality modeling, J. Geophys. Res., 95, 16343, doi:10.1029/JD095iD10p16343, 1990.

Sutton, M. A., Reis, S., Riddick, S. N., Dragosits, U., Nemitz, E., Theobald, M. R., Tang, Y. S., Braban, C. F., Vieno, M., Dore, A. J., Mitchell, R. F., Wanless, S., Daunt, F., Fowler, D., Black-

\section{ACPD}

15, 22935-22973, 2015

$\mathrm{NH}_{3}$ concentrations

over Europe - a static and dynamic

approach with

WRF-Chem

M. Werner et al.

\section{Title Page}

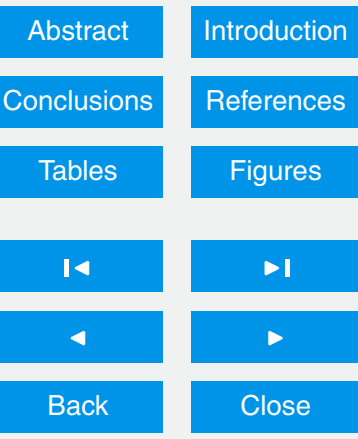

Full Screen / Esc

Printer-friendly Version

Interactive Discussion 
all, T. D., Milford, C., Flechard, C. R., Loubet, B., Massad, R., Cellier, P., Personne, E., Coheur, P. F., Clarisse, L., Van Damme, M., Ngadi, Y., Clerbaux, C., Skjøth, C. A., Geels, C., Hertel, O., Wichink Kruit, R. J., Pinder, R. W., Bash, J. O., Walker, J. T., Simpson, D., Horváth, L., Misselbrook, T. H., Bleeker, A., Dentener, F., and de Vries, W.: Towards a climate-dependent paradigm of ammonia emission and deposition, Philos. T. R. Soc. Lon. B, 368, 20130166, doi:10.1098/rstb.2013.0166, 2013.

Tørseth, K., Aas, W., Breivik, K., Fjæraa, A. M., Fiebig, M., Hjellbrekke, A. G., Lund Myhre, C., Solberg, S., and Yttri, K. E.: Introduction to the European Monitoring and Evaluation Programme (EMEP) and observed atmospheric composition change during 1972-2009, Atmos.

$10 \quad$ Chem. Phys., 12, 5447-5481, doi:10.5194/acp-12-5447-2012, 2012.

Vieno, M., Dore, A. J., Stevenson, D. S., Doherty, R., Heal, M. R., Reis, S., Hallsworth, S., Tarrason, L., Wind, P., Fowler, D., Simpson, D., and Sutton, M. A.: Modelling surface ozone during the 2003 heat-wave in the UK, Atmos. Chem. Phys., 10, 7963-7978, doi:10.5194/acp10-7963-2010, 2010.

Wałaszek, K., Kryza, M., and Werner, M.: Evaluation of the WRF meteorological model results during a high ozone episode in SW Poland - the role of model initial conditions, Int. J. Environ. Pollut., 54, 193-202, 2014.

Warrach-Sagi, K., Schwitalla, T., Wulfmeyer, V., and Bauer, H.-S.: Evaluation of a climate simulation in Europe based on the WRF-NOAH model system: precipitation in Germany, Clim. 20 Dynam., 41, 755-774, doi:10.1007/s00382-013-1727-7, 2013.

Wen, D., Zhang, L., Lin, J. C., Vet, R., and Moran, M. D.: An evaluation of ambient ammonia concentrations over southern Ontario simulated with different dry deposition schemes within STILT-Chem v0.8, Geosci. Model Dev., 7, 1037-1050, doi:10.5194/gmd-7-1037-2014, 2014.

Werner, M., Ambelas Skjøth, C., Kryza, M., and Dore, A. J.: Understanding emissions of ammonia from buildings and the application of fertilizers: an example from Poland, Biogeosciences, 12, 3623-3638, doi:10.5194/bg-12-3623-2015, 2015.

Wichink Kruit, R. J., Schaap, M., Sauter, F. J., van Zanten, M. C., and van Pul, W. A. J.: Modeling the distribution of ammonia across Europe including bi-directional surface-atmosphere exchange, Biogeosciences, 9, 5261-5277, doi:10.5194/bg-9-5261-2012, 2012.

so Xie, B., Fung, J. C. H., Chan, A., and Lau, A.: Evaluation of nonlocal and local planetary boundary layer schemes in the WRF model, J. Geophys. Res.-Atmos., 117, D12103, doi:10.1029/2011JD017080, 2012.

\section{ACPD}

15, 22935-22973, 2015

$\mathrm{NH}_{3}$ concentrations

over Europe - a static and dynamic

approach with

WRF-Chem

M. Werner et al.

\section{Title Page}

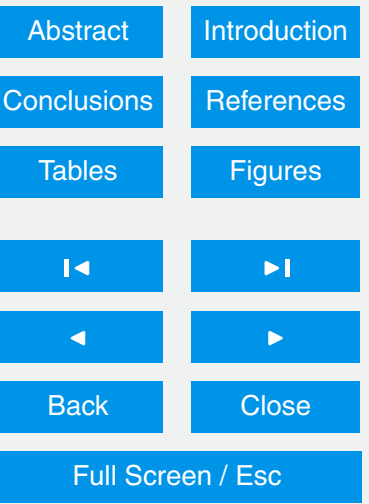

Printer-friendly Version

Interactive Discussion 
Zhang, Y., Wen, X.-Y., and Jang, C. J.: Simulating chemistry-aerosol-cloud-radiationclimate feedbacks over the continental U.S. using the online-coupled Weather Research Forecasting Model with chemistry (WRF/Chem), Atmos. Environ., 44, 3568-3582, doi:10.1016/j.atmosenv.2010.05.056, 2010.

5 Zhu, L., Henze, D., Bash, J., Jeong, G.-R., Cady-Pereira, K., Shephard, M., Luo, M., Paulot, F., and Capps, S.: Global evaluation of ammonia bi-directional exchange, Atmos. Chem. Phys. Discuss., 15, 4823-4877, doi:10.5194/acpd-15-4823-2015, 2015.

\section{ACPD}

15, 22935-22973, 2015

$\mathrm{NH}_{3}$ concentrations

over Europe - a static and dynamic approach with WRF-Chem

M. Werner et al.

\section{Title Page}

Abstract

Conclusions

Tables

14

4

Back
Introduction

References

Figures

$>1$

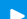

Full Screen / Esc

Printer-friendly Version

Interactive Discussion 
Table 1. Model components and configuration.

\begin{tabular}{ll}
\hline Category & Model setup \\
\hline Simulation period & Jan-Dec 2012 \\
Domains & Europe, $161 \times 131$ grids \\
Horizontal resolutions & $36 \mathrm{~km} \times 36 \mathrm{~km}$ \\
Vertical resolution & 48 layers \\
Shortwave and Longwave radiation & RRTMG \\
Land-surface model & Noah LSM \\
Boundary layer scheme & YSU \\
Cumulus parameterization & Grell and Denvenyi (2002) \\
Microphysics & Lin et al. (1983) \\
Chemistry & RADM2 and MADE/SORGAM with aqueous reactions \\
\hline
\end{tabular}

Please refer to the WRF and the WRF-Chem user's guides for a complete description of the options.

$\mathrm{NH}_{3}$ concentrations over Europe - a static and dynamic approach with WRF-Chem

M. Werner et al.

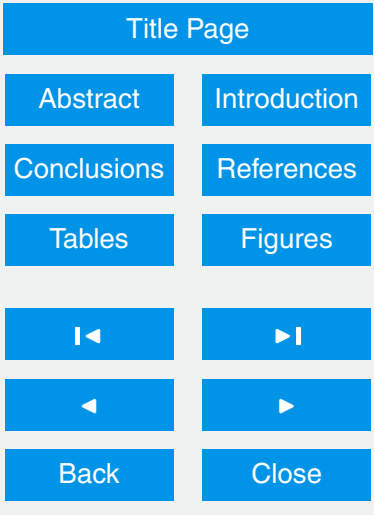

Full Screen / Esc

Printer-friendly Version

Interactive Discussion 
Table 2. Mean statistics based on hourly data $(N)$ for Harwell for 2012: FAC2 (factor of two), MB (mean bias), NMB (normalised mean bias), RMSE (root mean squared error), $R$ (correlation coefficient).

\begin{tabular}{llllllll}
\hline Season & $N$ & FAC2 & $\begin{array}{l}\mathrm{MB} \\
\mu \mathrm{gm}^{-3}\end{array}$ & $\begin{array}{c}\mathrm{BASE} \\
\mathrm{NMB} \\
\mu \mathrm{gm}^{-3}\end{array}$ & $\begin{array}{l}\mathrm{NMGE} \\
\mu \mathrm{gm}^{-3}\end{array}$ & $\begin{array}{l}\mathrm{RMSE} \\
\mu \mathrm{gm}^{-3}\end{array}$ & $R$ \\
\hline winter & 1491 & 0.60 & 0.44 & 0.60 & 0.98 & 1.31 & 0.36 \\
spring & 1949 & 0.47 & 0.91 & 0.35 & 0.82 & 2.94 & 0.44 \\
summer & 1156 & 0.36 & 0.35 & 0.33 & 0.97 & 1.33 & 0.22 \\
autumn & 1523 & 0.50 & 0.56 & 0.69 & 1.02 & 1.15 & 0.26 \\
\hline \multicolumn{7}{c}{ DYNAMIC } \\
\hline winter & 1491 & 0.64 & -0.12 & -0.16 & 0.52 & 0.63 & 0.45 \\
spring & 1949 & 0.47 & 2.26 & 0.87 & 1.23 & 5.60 & 0.57 \\
summer & 1156 & 0.35 & 0.52 & 0.49 & 1.07 & 1.50 & 0.28 \\
autumn & 1523 & 0.51 & 0.46 & 0.56 & 0.94 & 1.06 & 0.24 \\
\hline
\end{tabular}

ACPD

15, 22935-22973, 2015

$\mathrm{NH}_{3}$ concentrations

over Europe - a static and dynamic approach with WRF-Chem

M. Werner et al.

\section{Title Page}

\section{Abstract}

Conclusions

Tables

14

Back
Introduction

References

Figures

DI

Close
Full Screen / Esc

Printer-friendly Version

Interactive Discussion 
Table 3. Mean statistics for $\mathrm{NH}_{3}$ concentrations based on daily in $(N)$ observations from 6 sites (Harwell, Jarczew, Risø, Tange, Ulborg and Anholt) for 2012.

\begin{tabular}{llllllll}
\hline & $N$ & FAC2 & $\begin{array}{l}\mathrm{MB} \\
\mu \mathrm{gm}^{-3}\end{array}$ & $\begin{array}{l}\mathrm{NMB} \\
\mu \mathrm{m} \mathrm{m}^{-3}\end{array}$ & $\begin{array}{l}\mathrm{NMGE} \\
\mu \mathrm{g} \mathrm{m}^{-3}\end{array}$ & $\begin{array}{l}\mathrm{RMSE} \\
\mu \mathrm{gm}^{-3}\end{array}$ & $R$ \\
\hline BASE & 2020 & 0.38 & 0.93 & 1.10 & 1.28 & 1.76 & 0.55 \\
DYNAMIC & 2020 & 0.42 & 0.85 & 1.00 & 1.23 & 1.94 & 0.66 \\
\hline
\end{tabular}

15, 22935-22973, 2015

$\mathrm{NH}_{3}$ concentrations over Europe - a static and dynamic approach with WRF-Chem

M. Werner et al.

\section{Title Page}

\section{Abstract}

Conclusions

Tables

14

Back

Full Screen / Esc

Printer-friendly Version

Interactive Discussion 
Table 4. Mean statistics split into seasons for $\mathrm{NH}_{3}$ concentrations based on daily observations $(N)$ from 6 sites (Harwell, Jarczew, Risø, Tange, Ulborg and Anholt) for 2012.

\begin{tabular}{lllllllll}
\hline Season & $N$ & FAC2 & $\begin{array}{l}\mathrm{MB} \\
\mu \mathrm{gm}^{-3}\end{array}$ & $\begin{array}{l}\text { BASE } \\
\mathrm{Mgm}^{-3}\end{array}$ & $\begin{array}{l}\mathrm{NMB} \\
\mathrm{\mu gm}^{-3}\end{array}$ & $\begin{array}{l}\mathrm{NMGE} \\
\mathrm{\mu gm}^{-3}\end{array}$ & $\begin{array}{l}\mathrm{RMSE} \\
\mu \mathrm{m} \mathrm{m}^{-3}\end{array}$ & $R$ \\
\hline winter & 502 & 0.22 & 1.18 & 1.21 & 3.65 & 3.75 & 2.10 & 0.34 \\
spring & 539 & 0.46 & 1.34 & 1.60 & 0.87 & 1.04 & 2.34 & 0.57 \\
summer & 491 & 0.46 & 0.57 & 0.72 & 0.69 & 0.86 & 0.98 & 0.60 \\
autumn & 488 & 0.37 & 0.58 & 0.76 & 0.92 & 1.19 & 1.09 & 0.46 \\
\hline \multicolumn{7}{c}{ DYNAMIC } \\
\hline winter & 502 & 0.38 & 0.20 & 0.34 & 0.61 & 1.06 & 0.49 & 0.42 \\
spring & 539 & 0.46 & 1.71 & 1.97 & 1.11 & 1.28 & 3.22 & 0.66 \\
summer & 491 & 0.49 & 0.56 & 0.71 & 0.67 & 0.85 & 0.97 & 0.63 \\
autumn & 488 & 0.33 & 0.84 & 1.06 & 1.32 & 1.65 & 1.72 & 0.27 \\
\hline
\end{tabular}

15, 22935-22973, 2015

$\mathrm{NH}_{3}$ concentrations

over Europe - a static and dynamic approach with WRF-Chem

M. Werner et al.

\section{Title Page}

\section{Abstract}

Conclusions

Tables

14

Back
Introduction

References

Figures

DI

Close

Full Screen / Esc

Printer-friendly Version

Interactive Discussion 

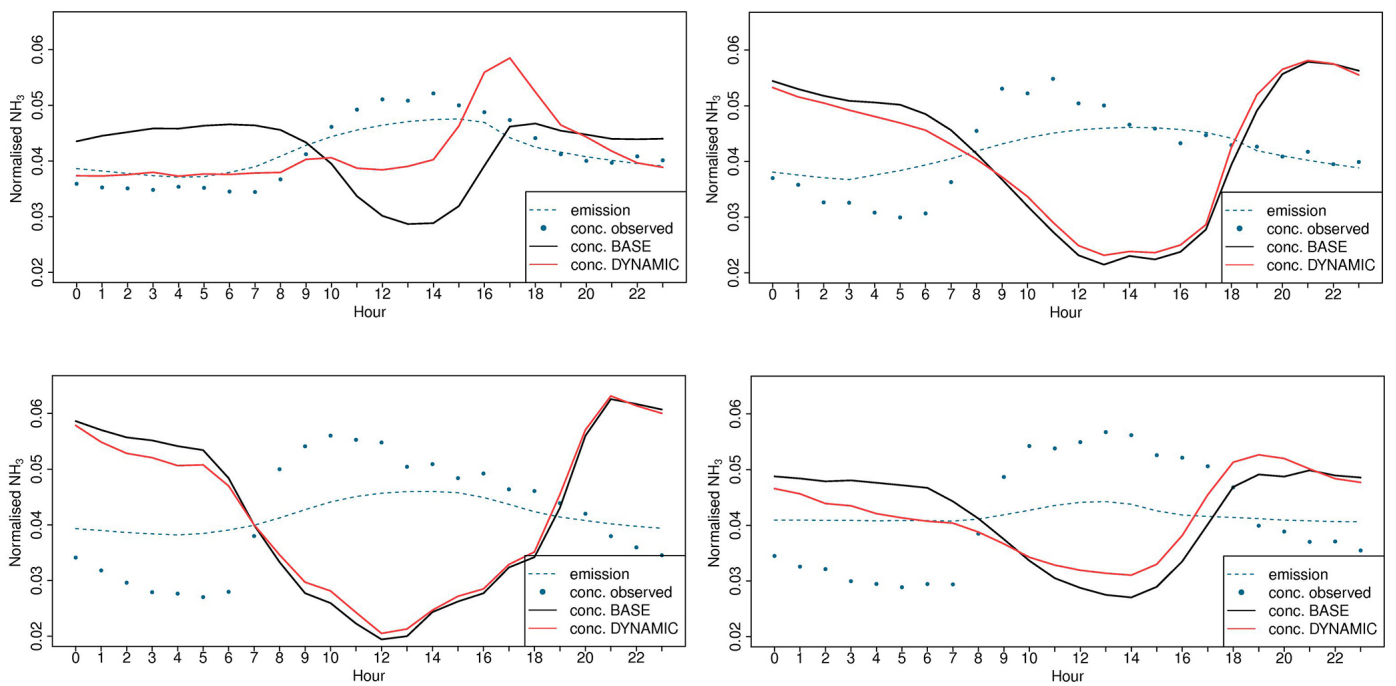

Figure 1. Normalised $\mathrm{NH}_{3}$ concentrations and emission according to hours for four seasons for the grid corresponds to the Harwell station. Normalisation procedure: the sum of emission/concentration for each individual hour (0-23) was divided by the total sum of emission/concentration in the season.

$\mathrm{NH}_{3}$ concentrations over Europe - a static and dynamic approach with WRF-Chem

M. Werner et al.

\section{Title Page}

\section{Abstract}

Conclusions

Tables

14

Full Screen / Esc

Printer-friendly Version

Interactive Discussion 

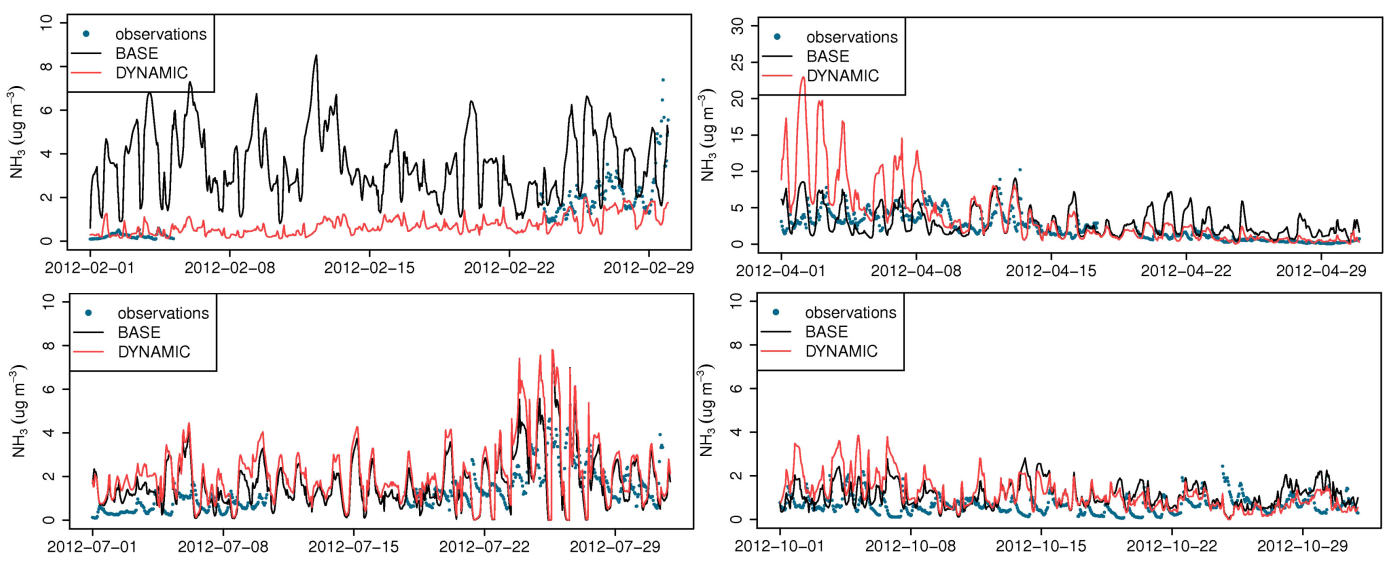

\section{ACPD}

15, 22935-22973, 2015

$\mathrm{NH}_{3}$ concentrations over Europe - a static and dynamic approach with WRF-Chem

M. Werner et al.

\section{Title Page}

\section{Abstract}

Conclusions

Tables

14

Back
Introduction

References

Figures

\section{Close}

Full Screen / Esc

Printer-friendly Version

Interactive Discussion 


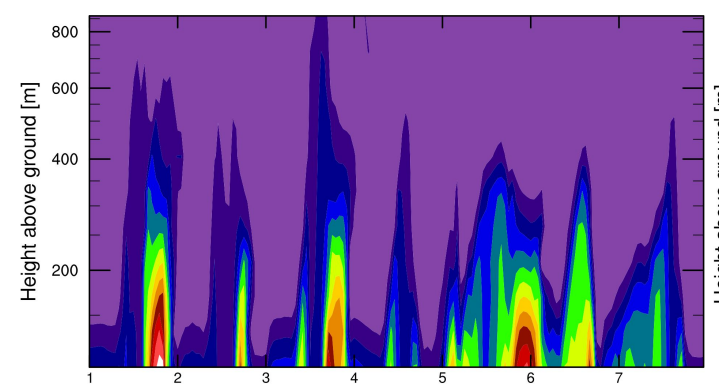

Day of February 2012
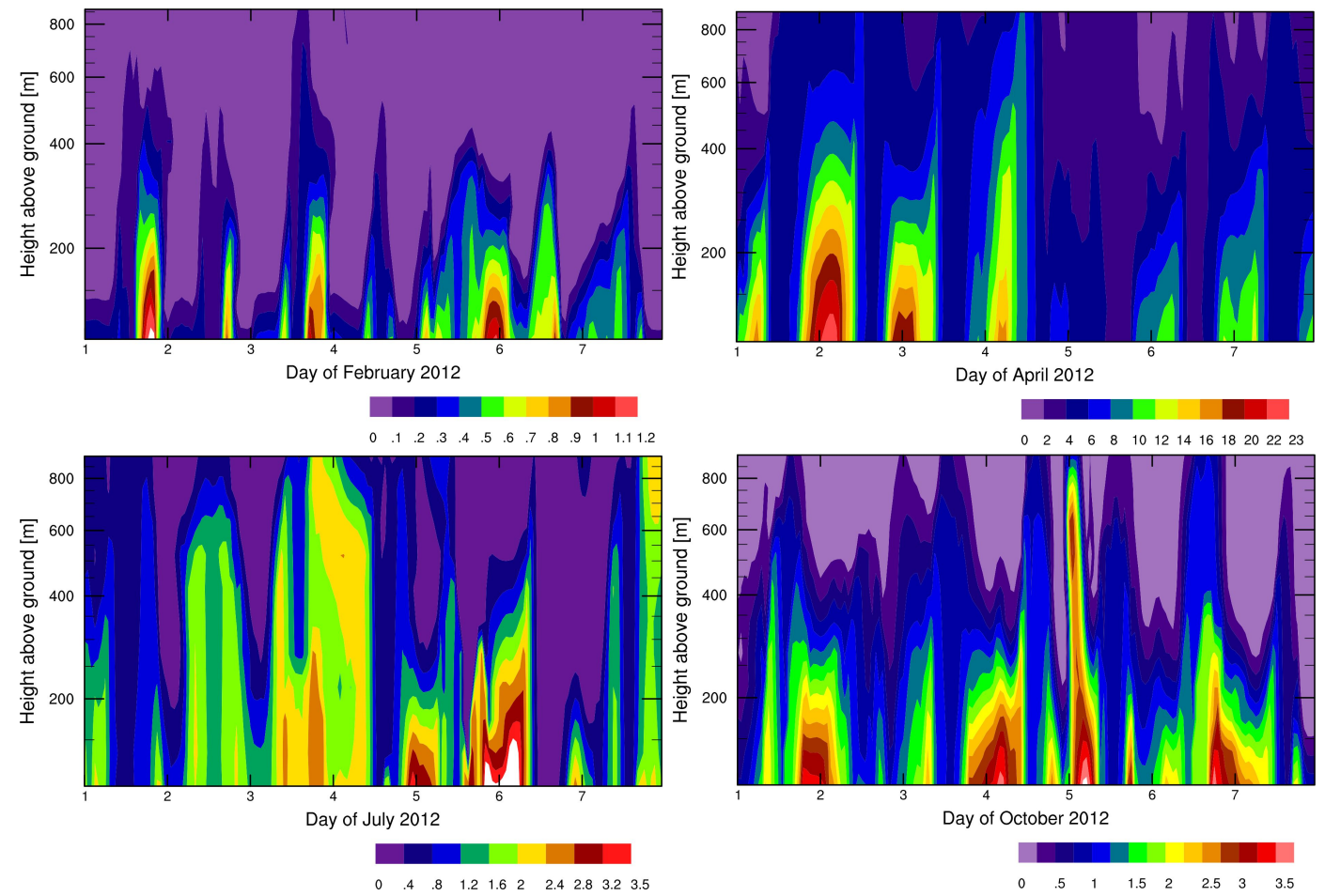

Day of April 2012

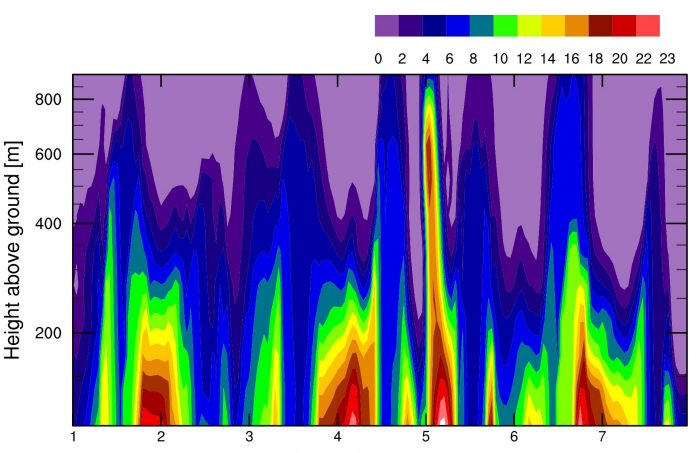

Day of October 2012

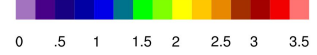

Figure 3. Temporal and vertical distribution of $\mathrm{NH}_{3}$ concentrations $\left[\mathrm{\mu g} \mathrm{m}^{-3}\right]$ for the DYNAMIC scenario.

\section{ACPD}

15, 22935-22973, 2015

$\mathrm{NH}_{3}$ concentrations over Europe - a static and dynamic approach with WRF-Chem

M. Werner et al.

\section{Title Page}

Abstract

Conclusions

Tables

14

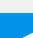

Back

Full Screen / Esc

Printer-friendly Version

Interactive Discussion
Introduction

References

Figures

$>1$

$>$

Close 

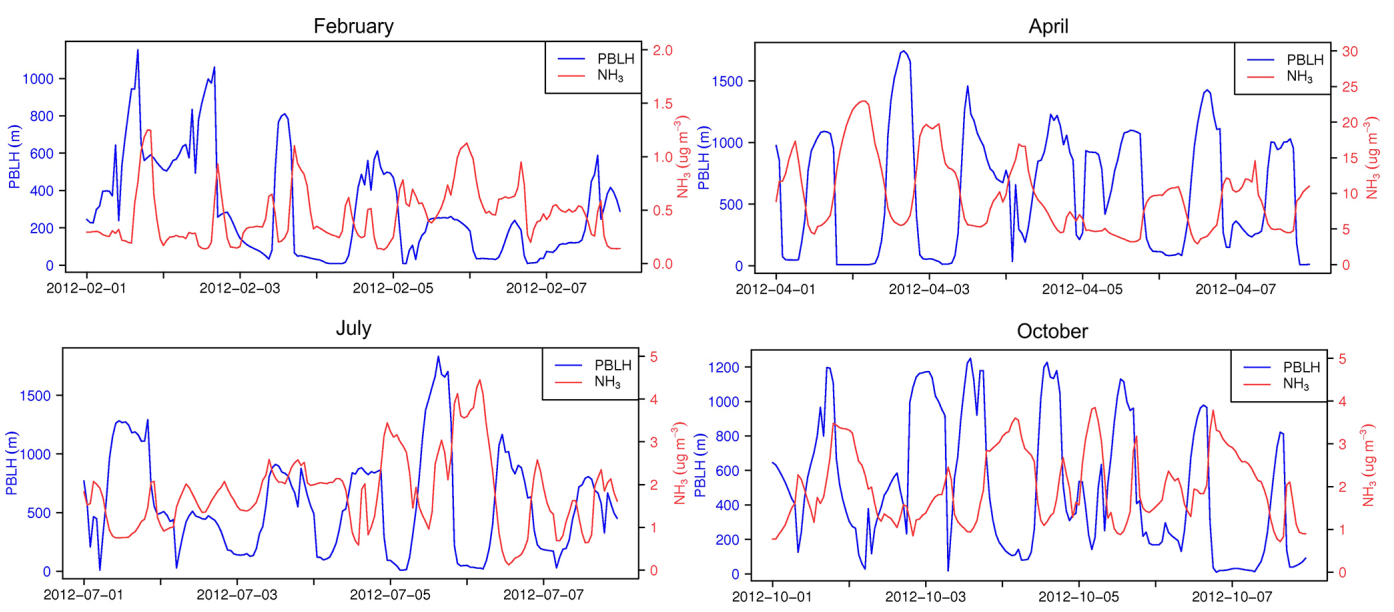

Figure 4. Time series of modelled (DYNAMIC) PBLH and $\mathrm{NH}_{3}$ concentrations for the episode of February, April, July and October 2012.

\section{ACPD}

15, 22935-22973, 2015

$\mathrm{NH}_{3}$ concentrations over Europe - a static and dynamic approach with WRF-Chem

M. Werner et al.

\section{Title Page}

\section{Abstract}

Introduction

Conclusions

References

Tables

Figures

14

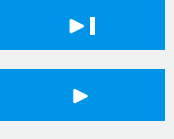

Back

Close

Full Screen / Esc

Printer-friendly Version

Interactive Discussion 

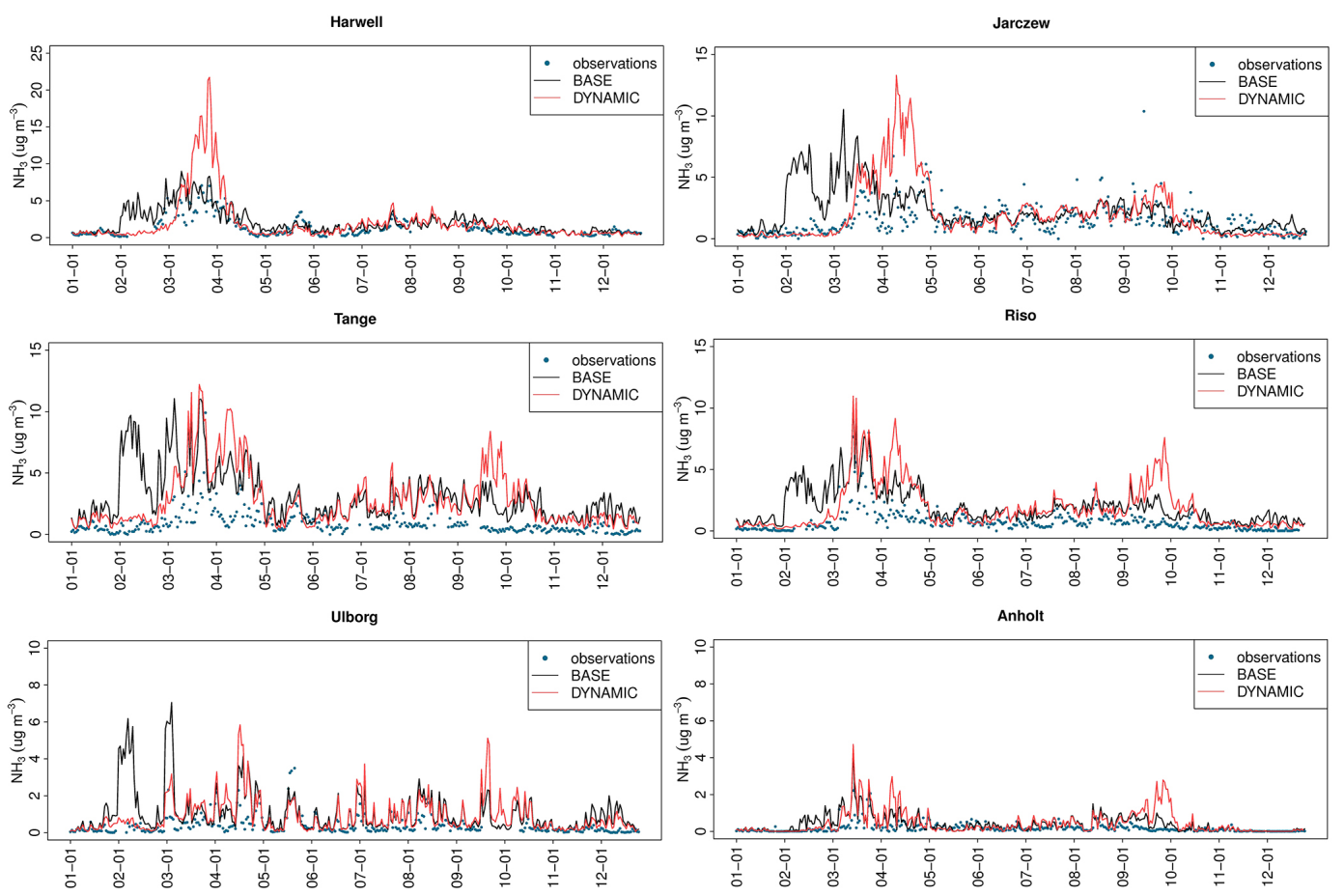

Figure 5. Modelled and observed daily $\mathrm{NH}_{3}$ concentrations for 2012. Different $y$ axis scales are used for the different stations.
ACPD

15, 22935-22973, 2015

$\mathrm{NH}_{3}$ concentrations over Europe - a static and dynamic approach with WRF-Chem

M. Werner et al.

Title Page
Abstract

Conclusions

Tables

14

Back
Introduction

References

Figures

- I

\section{Full Screen / Esc}

Printer-friendly Version

Interactive Discussion 

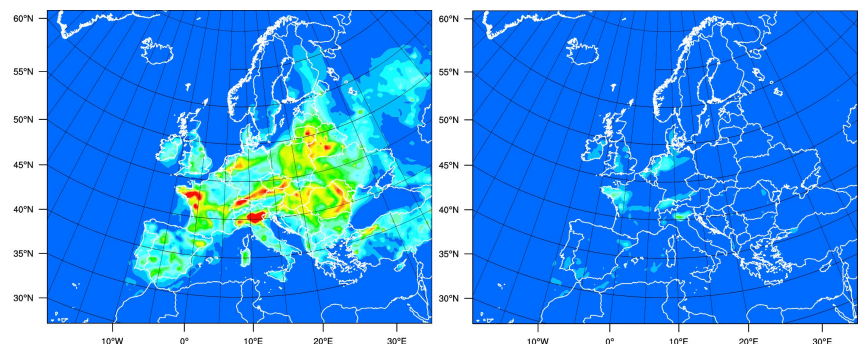

\section{ACPD}

15, 22935-22973, 2015

$\mathrm{NH}_{3}$ concentrations over Europe - a static and dynamic approach with WRF-Chem

M. Werner et al.

\section{Title Page}

\section{Abstract}

Conclusions

Tables

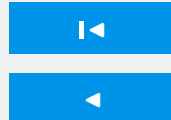

Back
Introduction

References

\section{Figures}

$\rightarrow \mathbf{I}$

Close

Figure 6. Spatial distribution of $\mathrm{NH}_{3}$ concentrations on 15 February (upper), 15 April (middle), and 15 October (lower) 2012 at 12.00 a.m. BASE scenation - left column, DYNAMIC scenario

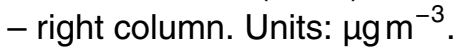

\section{Full Screen / Esc}

Printer-friendly Version

Interactive Discussion 


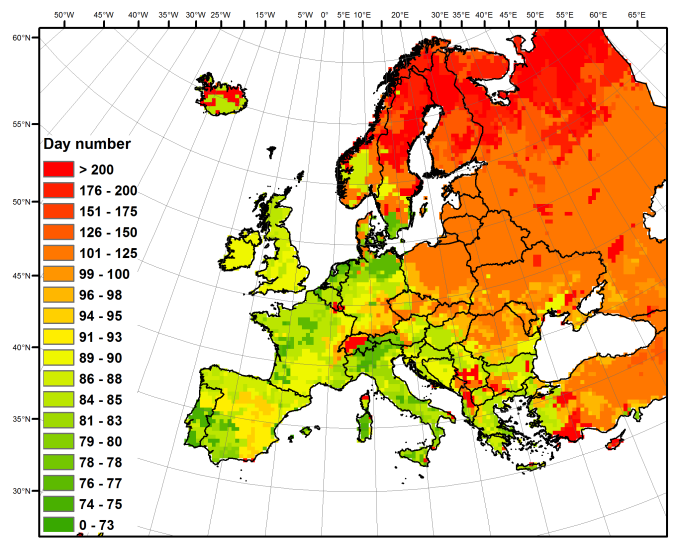

\section{ACPD}

15, 22935-22973, 2015

$\mathrm{NH}_{3}$ concentrations over Europe - a static and dynamic approach with WRF-Chem

M. Werner et al.

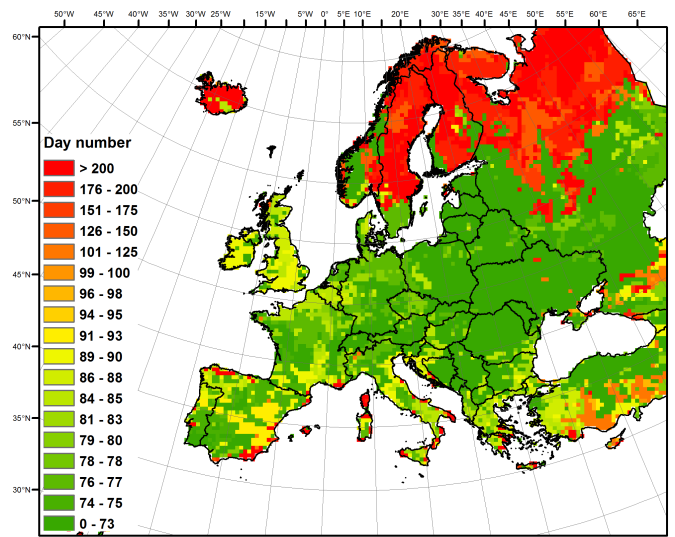

Title Page

\section{Abstract}

Conclusions

Tables

14

Back

Full Screen / Esc

Printer-friendly Version

Interactive Discussion 

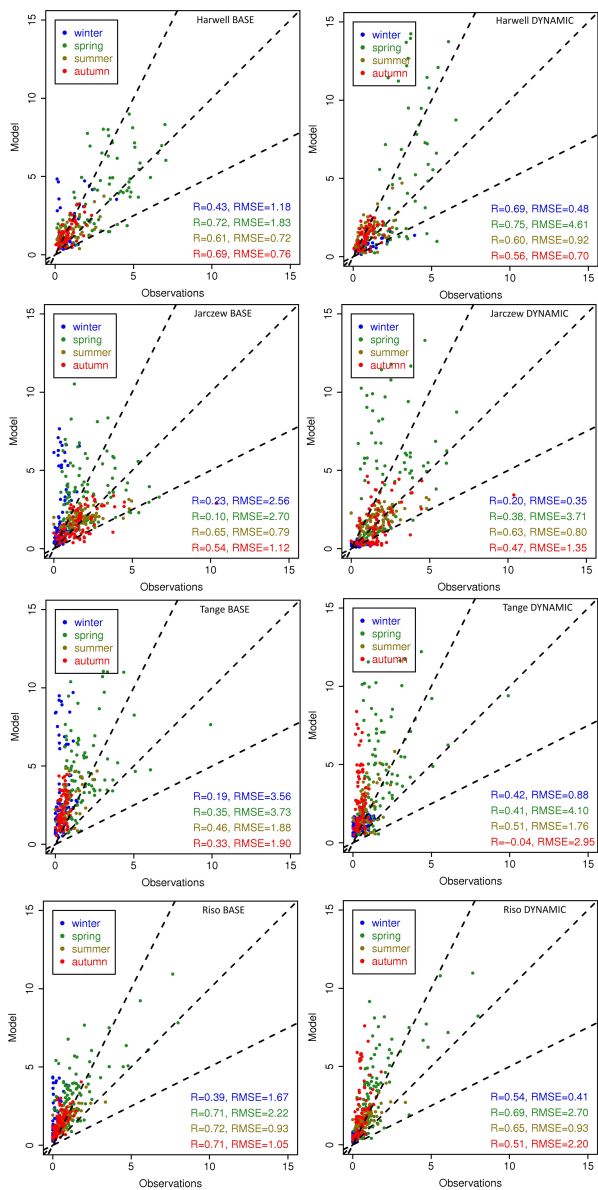

Figure 8. Scatter plots of $\mathrm{NH}_{3}$ concentrations based on daily values for individual sites for the BASE (left) and DYNAMIC (right) simulations and according to seasons.

ACPD

15, 22935-22973, 2015

$\mathrm{NH}_{3}$ concentrations over Europe - a static and dynamic approach with WRF-Chem

M. Werner et al.

Title Page

\section{Abstract}

Conclusions

Tables

14

Back
Introduction

References

Figures

$>1$

Close
Full Screen / Esc

Printer-friendly Version

Interactive Discussion 